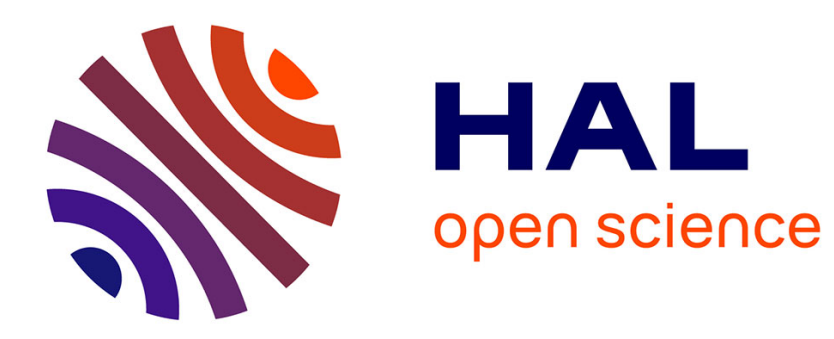

\title{
Southern Europe's institutional decline
}

Edouard Challe, Jose Ignacio Lopez, Eric Mengus

\section{To cite this version:}

Edouard Challe, Jose Ignacio Lopez, Eric Mengus. Southern Europe's institutional decline. 2016. hal-01331723

\section{HAL Id: hal-01331723 \\ https://hal.science/hal-01331723}

Preprint submitted on 14 Jun 2016

HAL is a multi-disciplinary open access archive for the deposit and dissemination of scientific research documents, whether they are published or not. The documents may come from teaching and research institutions in France or abroad, or from public or private research centers.
L'archive ouverte pluridisciplinaire HAL, est destinée au dépôt et à la diffusion de documents scientifiques de niveau recherche, publiés ou non, émanant des établissements d'enseignement et de recherche français ou étrangers, des laboratoires publics ou privés. 


\title{
ECOLE POLYTECHNIQUE
}

\section{Southern Europe's institutional decline}

\author{
Edouard CHALLE \\ Jose Ignacio LOPEZ \\ Eric MENGUS
}

June 9, 2016

Cahier $\mathrm{n}^{\circ}$ 2016-08

\section{DEPARTEMENT D'ECONOMIE}

Route de Saclay

91128 PALAISEAU CEDEX

(33) 169333033

http://www.portail.polytechnique.edu/economie/fr

mariame.seydi@polytechnique.edu 


\title{
Southern Europe's institutional decline*
}

\author{
Edouard Challe
}

Jose Ignacio Lopez

June 9, 2016
Eric Mengus

\section{PRELIMINARY}

\begin{abstract}
The run up to the euro currency initiated a period of capital inflows into southern European countries, i.e., Spain, Portugal, Italy and Greece. We document that those countries, and only them among OECD countries, concomitantly experienced a decline in the quality of their institutions. We confirm the joint pattern of capital inflows and institutional decline in a large panel of countries. We show theoretically that this joint pattern naturally follows from a "soft budget constraint" syndrome wherein persistently cheap external funding undermines incentives to maintain good institutions -understood here as the degree of government commitment not to support inefficient firms. Low institutional quality ultimately raises the share of inefficient firms, which lowers average productivity and raises productivity dispersion across firms -the typical pattern of productivity in southern Europe over the period under consideration.
\end{abstract}

Keywords: TFP, institutions, current account.

\section{JEL Classification: .}

*Challe: Ecole Polytechnique and CREST (UMR 9194), Email: edouard.challe@gmail.com. Ecole Polytechnique, Departement of Economics, Route de Saclay, 91128 Palaiseau, France. Lopez: HEC, lopez@hec.fr. Mengus: HEC, mengus@hec.fr. HEC Paris. Economics and Decision Sciences Department, 1 rue de la Liberation, 78350 Jouy-en-Josas, France. We thank Jean Barthelemy, Ai-Ting Goh, Tomasz Michalski, Mario Pietrunti and Guillaume Vuillemey as well as participants to the 2016 EACBN conference (Zurich) for helpful comments. All remaining errors are ours. 


\section{Introduction}

Institutions, broadly defined as the set of rules and constraints that shape economic behavior and incentives, are a key determinant of economic development. ${ }^{1}$ The importance of the quality of institutions for development unambiguously shows up both in cross-country regressions and in case studies of comparative economic development (see, e.g., Hall and Jones, 1999; Acemoglu, 2009; Acemoglu and Robinson, 2012). Despite their crucial role, institutions are often ignored or taken as given in discussions of economic policy, like trade or financial liberalizations, because institutions are considered in many dimensions as slow-moving and most indicators of institutional quality are highly persistent, especially for developed economies. Institutions, however, are not static and exogenous; they are to some extent an outcome of economic developments. In particular, institutions may decay if the perceived benefits of maintaining and implementing an efficient set of rules start falling short of the costs.

In this paper, we study empirically and theoretically the link between capital inflows and the quality of institutions, and conclude that the former negatively impact the latter. We use the run-up to, and creation of, the euro currency as a quasi-natural experiment of falling borrowing costs and large capital inflows into southern European countries (Spain, Portugal, Italy and Greece), and show that those inflows were associated with a significant decline in the quality of institutions (Sections 2.1 and 2.2). This decline starts well before the financial crisis of 2008, shows up in a broad range of indicators, and has no parallel anywhere else in the developed world over this period. This experience contrasts with that of other eurozone members, which experienced neither a drastic change in the pattern of capital flows nor an institutional decay, and also, to some extent, with European countries outside the euro-area. ${ }^{2}$

Next, using in a large panel of countries, over the period for which consistent data on institutional quality is available, we confirm that persistent capital inflows are systematically followed by a decline in the quality of domestic institutions (Section 2.4). This systematic relation is unrelated to the standard "dutch disease", as it is stronger when we exclude economies with high oil rent. Furthermore, this connection is nonlinear in the initial level of institutional quality, in that it is stronger when we exclude countries with either very high or very low initial levels of institutional quality. This suggests, first, that countries with very good institutions (according to our indicators) are less susceptible to experience a drastic change in the quality of their institutions following large capital inflows (e.g., the US and the UK in

\footnotetext{
${ }^{1}$ Douglas North (1991) notoriously defined institutions as the "humanly devised constraints that structure political, economic and social interactions", whether these constraints be formal ("constitution, laws, property rights") or informal ("sanctions, taboos, customs, traditions and codes of conduct").

${ }^{2}$ In the Eurozone Ireland did received capital inflows without experiencing an institutional decline, but these inflows took the form of FDIs rather than portfolio investment. We discuss this difference further below.
} 
our sample); and second, that countries with institutions whose quality is already very low in the first place may not seen them worsening significantly more when capital flows in.

Based on these observations, we propose a theoretical model that naturally rationalizes the observed link between capital inflows and the decline in the quality of institutions (Section 3). The model builds on the "soft budget constraint" literature, which emphasizes the distortions in private investment decisions resulting from the inability of the government to commit to future policies. ${ }^{3}$ In our model economy, domestic investors provide funding to domestic firms out of their own cash and also using money borrowed from abroad - up to a borrowing constraint that is tied to domestic investors' pledgeable income. Domestic firms are endowed with projects that are either efficient or inefficient, compete for domestic investors' funding but are indistinguishable by them. Efficient projects have positive net present value (NPV) and require no reinvestment ex post. In contrast, inefficient projects requires some reinvestment to pay out and, while they have negative NPV ex ante, it may be worthwhile to reinvest in them ex post once the initial start-up cost has been sunk. In this situation, a benevolent government may not resist the temptation to rescue inefficient firms, provided that the cost of doing so is sufficiently low. When private agents anticipate that it will not resist this temptation, external capital flows in as all firms, including the inefficient ones, submit their project for funding.

Within this framework, we model the quality of institution as the relative ability of the government to commit not to refinance inefficient projects ex post. Maintaining the quality of institutions, however, is costly, and hence must be weighed against the benefits associated with limiting the extent of inefficient investment. We think of the costs of institutional quality not only as pecuniary costs (e.g., the cost of implementing an effective legal and judicial system, of maintaining efficient regulatory and supervisory authorities in competition, banking, etc.) but also as less direct, non-pecuniary costs such as the political cost of reducing future politicians' discretion. In this context, low interest rates reduce the social cost of inefficient projects and, therefore, the relative benefits of commitment. ${ }^{4}$ In equilibrium, the lower the interest

\footnotetext{
${ }^{3}$ Maskin (1996) succinctly defines the "soft budget constraint syndrome" as a situation in which a "funding source" e.g. a bank or government finds it impossible to keep an enterprise to a fixed budget, i.e., whenever the enterprise can extract ex post a bigger subsidy or loan than would have been considered efficient ex ante. The syndrome was initially identify by Kornai (1979), who argued that even profit-maximizing state-owned firms in socialist economies could safely anticipated to be bailed out ex post which led to inefficient investment ex ante. Dewatripont and Maskin (1995) showed that the same syndrome could arise in capitalist economies whenever some centralization of credit provision is at work. See Kornai et al. (2003) for an exhaustive survey of the literature on the soft budget constraint problem.

${ }^{4}$ Farhi and Tirole (2012) also establish, in a different context, a connection between excess borrowing and the inability of the government to commit to optimal bail-out policies. In their model, ex post bail-outs concern financial intermediaries rather than firms and occur due to a strategic complementarity between the balance-sheet exposures of individual banks. The difference between the soft budget syndrome in their model and in ours fundamentally lies in the direction of causality. In their model, the risk exposure decisions of
} 
rate, the lower the quality of institutions and the greater the number of inefficient projects being undertaken. Interestingly, the effect of the interest rate on the number of inefficient firms is non linear with respect of the initial share of inefficient projects, thus reproducing the non-linear pattern observed in the data with respect to the initial level of institutional quality.

Finally, our model also has predictions regarding the link between capital inflows and the level and dispersion of productivity: by degrading domestic institutions, capital inflows raise the share of inefficient projects, and thereby lower average firms' productivity and increase the dispersion of productivity across firms. According to our model, this effect should show up economy-wide, rather than being concentrated in some particular sectors (like the tradable sector or sectors with greater external financial dependence). We evaluate this prediction empirically and confirm this pattern for southern Europe since the mid-1990s (Section 4).

Related literature. Our paper contributes to the literature on institutions and economic outcomes by documenting an adverse effect of large and persistent capital inflows on the quality of domestic institutions and, ultimately, aggregate productivity. A number of papers study countries having experienced commodity booms, and discuss whether the revenues associated commodity windfalls lead to weaker institutions and economic growth. Sachs and Warner (1995) suggest that resource abundance can lead a to a deterioration of institutional quality and economic growth. Acemoglu and Ucer (2015) provide an example of institutional reversal leading to a sudden worsening of economic prospects, namely that which occurred in Turkey after the collapse of the Turkey-EU relations in the mid-2000s. Lane and Tornell (1996), Tornell and Lane (1999) document the poor economic performance of countries like Nigeria, Venezuela and Mexico after having benefited from large oil windfalls. Using crosscountry data Di Tella and Ades (1999) document that large rents from natural resources can increase domestic corruption. Acemoglu et al. (2004) suggest that high commodity rents facilitate dictators to reduce political competition. There is also evidence suggesting that the overall effect of commodity booms depends on the initial level of institutions. Acemoglu et al. (2003) argue that the high growth rates in per-capita income in Botswana in the middle of a commodity boom are explained by good institutions. Mehlum et al. (2006) argue that the resource curse depends on the initial level of institutional quality, while Robinson et al. (2006) suggest that the rents created by the commodity windfall can exacerbate inefficiencies in the domestic economy. Relative to those papers, our contribution is to document and individual banks create incentives for the government to manipulate banks' refinancing rate down, while in our model it is low world interest rates that make it optimal to start up inefficient projects. 
explain another external cause of domestic institutional decline, working through easy external borrowing and soft budget constraints.

Our paper also belongs to the growing strand of the literature that seeks to identify the relatively poor economic performance of Southern European countries since the the late 1990s, that is, at a time of worldwide economic expansion and well before the Great Recession. (see also Reis, 2013; Gopinath et al., 2015; Benigno et al., 2015; Dias et al., 2015; Cette et al., 2015, among others). We discuss this literature in some some details in Section 4, when examining the implications of our model for the distribution of productivity.

\section{The quality of institutions in the OECD, the Euro- zone, and southern Europe}

In this section, we investigate the evolution of institutional quality from the mid-1990s onward in OECD countries. Our main finding is that southern European countries stand out among European countries, and more generally among OECD countries, in that they were the only countries that experienced a significant decline in the quality of their institutions. Then, we correlate these evolutions with capital flows and show that countries having experienced an institutional decay were also important capital receivers during the run-up to, and first decade of, the euro. More generally, we show that there is a systematic negative relationship between large and persistent capital inflows and the evolution of the quality of institutions in a large panel of countries.

\subsection{The evolution of institutions}

In this subsection, we document that the south of Europe (that is: Greece, Italy, Portugal and Spain) experienced a decline in the quality of their institutions over the period under consideration. To this purpose, we analyze different measures of institutional quality for the OECD countries provided by the World Bank's World Governance Indicators (WGI).

The WGI indexes. This database covers 215 countries and characterizes the quality of a country's institutions using six measures of the quality of their governance: Voice and Accountability and Political Stability (on the selection, monitoring and replacement of governments), Government Effectiveness and Regulatory Quality (on the quality of government's policies) and Control of Corruption and the Rule of Law (on both the citizens and the state's behavior with respect to institutions). To be more specific, the Voice and Accountability 
index measures the ability of one country's citizens to participate in the selection of their government as well as freedom of speech and free medias, while the Political Stability index determines the perception of the probability that the government can be destabilized. The Government Effectiveness index assesses the quality of public services and of the civil service (e.g. independence from political pressures) as well as the quality of policy formulation and the credibility of the government to implementation them. The Regulatory Quality index focuses on the perception of the ability of the government to implement sound policies and regulations for developing private sector activity. Finally, the Rule of Law index measures the citizens' confidence in, and respect for, the country's laws and regulations. This index notably aggregate information on contract enforcement, property rights, the police and the courts as well as crime. Finally, the Control of Corruption index determines whether public policies favor private interests (via different forms of corruption or capture by elites or private interests). The WGI indexes are constructed by aggregating data from multiple sources, privatelyor publicly available, private or public sources. In particular, they gather data from both "experts" (multilateral development agencies or nongovernmental organizations) and surveys of domestic individuals and firms. We provide in the Appendix the exact list of data sources, as given by Kaufmann et al. (2010), as well as additional data descriptions. These different data sources are then aggregated using an Unobserved Component model, where each data source is considered as an imperfect signal of the actual level of the index. The resulting estimate of the index is normalized so that its distribution across countries is normal with mean 0 and variance $1 .^{5}$ Hence, most realizations of this index take values between -2 and 2, and the world average remains constant at 0 overtime. The unobserved component model also provides confidence intervals, which we can use to test the significance of any given evolution in the quality of institutions.

The quality of institutions in southern Europe. Figure 1 plots the six WGI indexes of institutional quality for Greece, Italy, Spain and Portugal between 1996 and 2011 compared with the rest of the euro-area. We focus on this time window for two reasons. First, while there exists measures of institutional quality that predate 1996 (e.g., the information used by Hall and Jones (1999) to construct their index of "social infrastructure"), 1996 is the first year where the WGI indexes are available, and to the best of our knowledge those provide the only broad and consistent yearly measures of institutional quality. Second, and as discussed in the introduction, our theory connects the quality of domestic institutions to the rise in capital

\footnotetext{
${ }^{5}$ See Kaufmann et al. (2010) for details. Note that the way the indexes are normalized implies that they capture the evolutions of a particular country or group of countries relative the world average, not in absolute terms
} 
inflows. In the wake of the sovereign debt crisis of 2010, the four above-mentioned countries experienced a capital flow reversal (a "sudden stop"), and 2011 is the last year where their current accounts were all negative.

As is apparent from Figure 1, the general trend in institutional quality over that period is decreasing. The timing of the decrease is sometimes different across countries or across indicators, but in general institutional quality has decreased or at best stagnated. An exception is Regulatory Quality, which first improved in the first years of the common currency but has finally started decreasing in the mid-2000s. For all the indicators and for all four countries, the decline was initiated long before the financial crisis of 2008-2009 and the European sovereign debt crisis in 2010. This decline contrasts with the the rest of the Eurozone ("North Europe"), where institutional quality is roughly unchanged over the period under consideration.

Was the south of Europe specific or did other countries in the euro-area, or more generally among OECD countries, also experience this declining trend? We can obtain a first-pass answer to this question by plotting the levels of some indexes in 2011 as a function of their values in 1996, for all OECD country - see Figure 2. Considering the Rule of Law index, it is striking that the four southern European countries stand out not only because the level of the index was initially lower than that in other OECD countries, but also because they are the only countries wherein this index has deteriorated -and substantially so (the four countries lie well below the 45-degree line). The same general pattern can also be observed, to a lesser extent, from the other indexes, such as the Government Efficiency and the Control of Corruption indexes.

Yet, the indexes are only estimates of institutional quality and, are such, they are measured with error. We can formally test whether the decline in the level of a particular index is significant using the standard deviations provided with the WGI database estimates. Table 1 reports p-values from Wald tests that check whether the value of each indicator in 2011 is significantly lower from its value in 1996. To put these p-values into perspective, note that Kaufmann et al. (2010) document that, over the 2000-2009 period and for each indicator, only $8 \%$ of countries experienced a significant change at the $10 \%$ level and $18 \%$ of countries at the $25 \%$ level. ${ }^{6}$ Due to its complex dynamics, we do not test the evolution of regulatory quality. For the other indexes, the Wald tests confirm the visual impressions provided by Figures 1 and 2 .

In the end, all four countries have experienced a decline in the quality of institutions that is significant for at least one of the indexes at the $5 \%$ level and usually significant for the

\footnotetext{
${ }^{6}$ Given the normalization of the indicators, this implies that $9 \%$ of countries experienced a significant decline at the $25 \%$ level, which corresponds to 19 countries.
} 


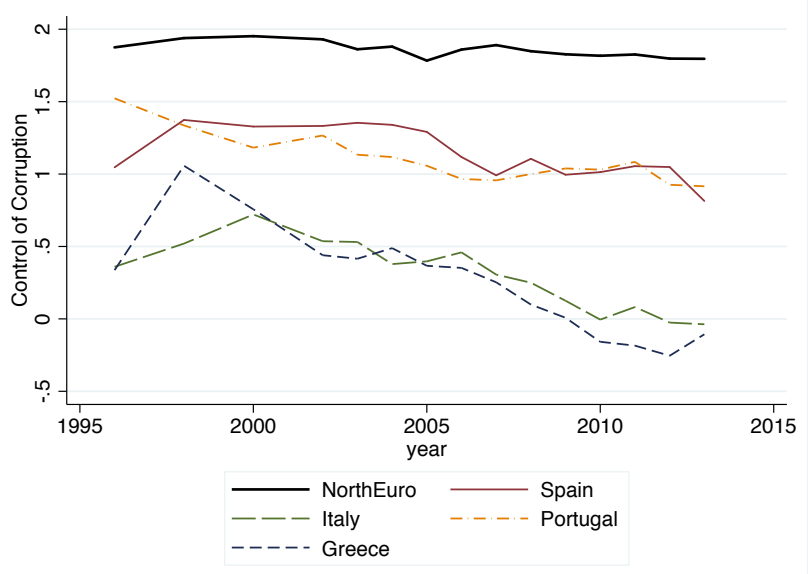

(a) Control of Corruption

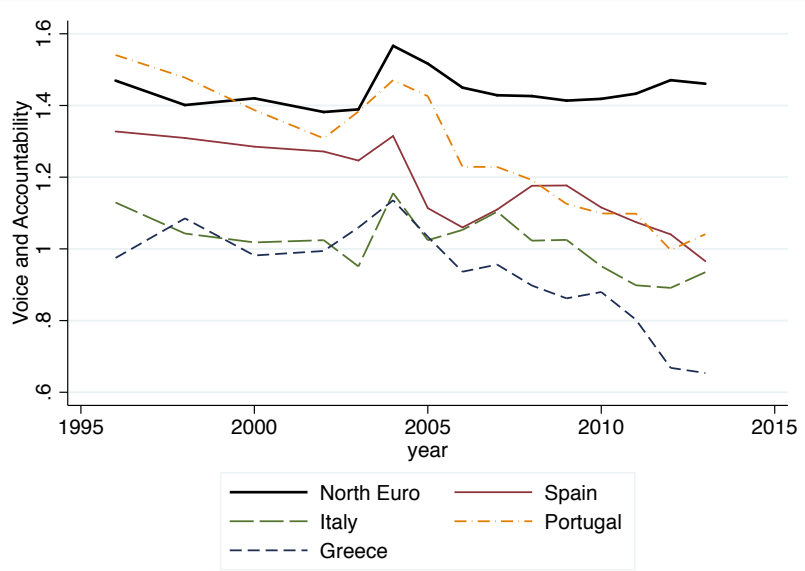

(c) Voice and Accountability

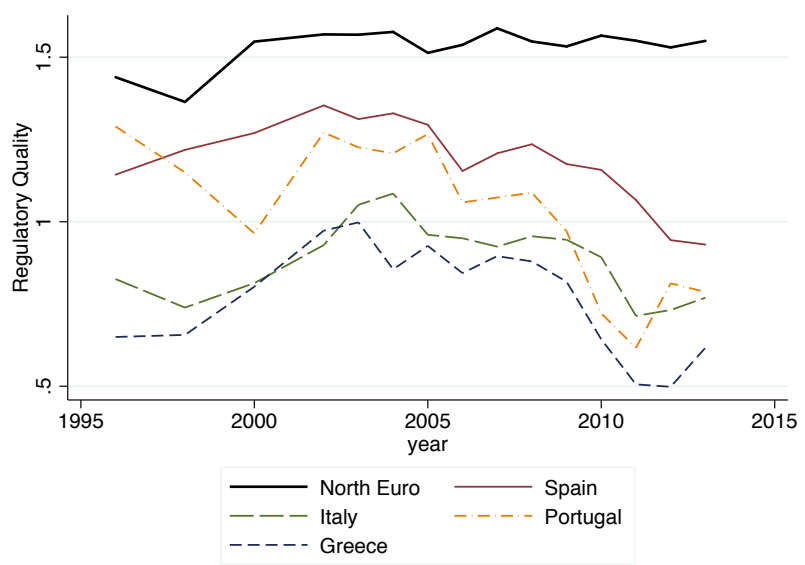

(e) Regulatory Quality

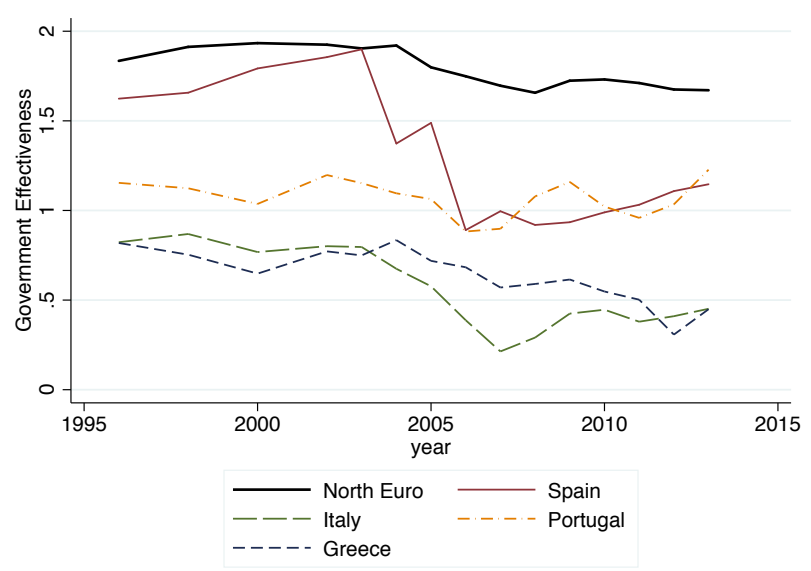

(b) Government Efficiency

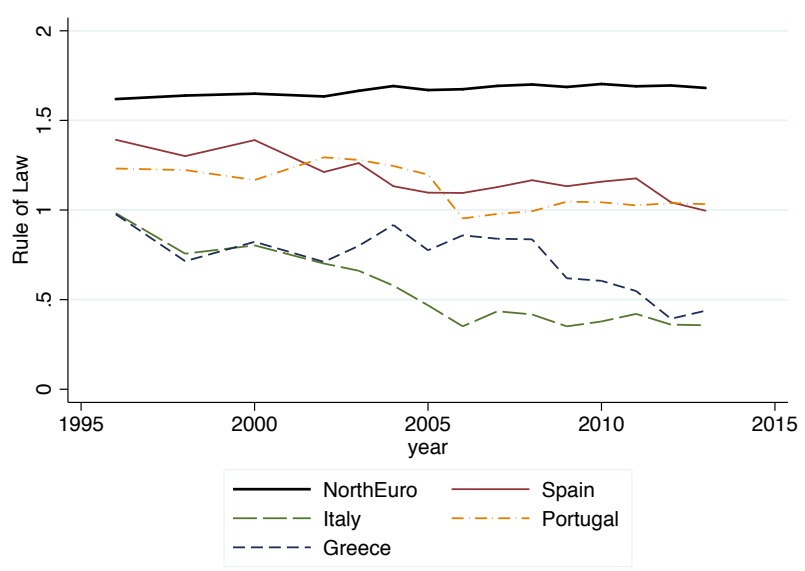

(d) Rule of Law

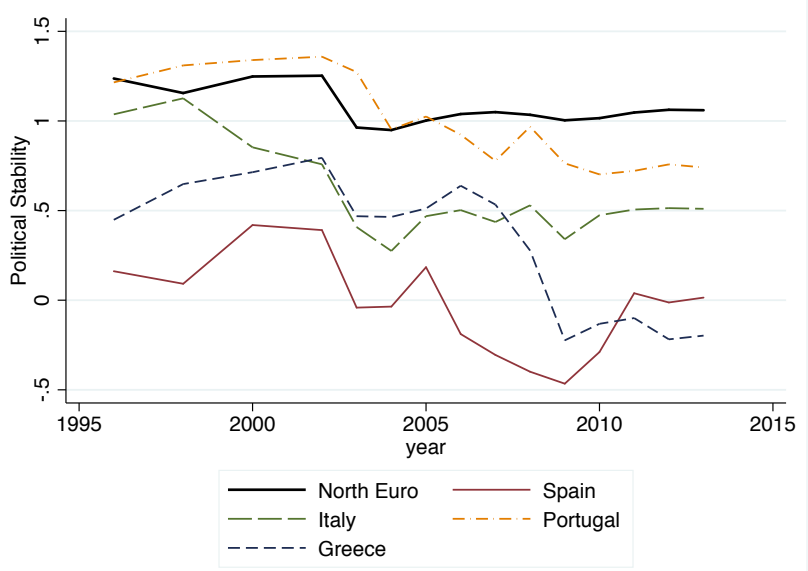

(f) Political Stability

Figure 1 - World Bank Indexes of institutional quality 


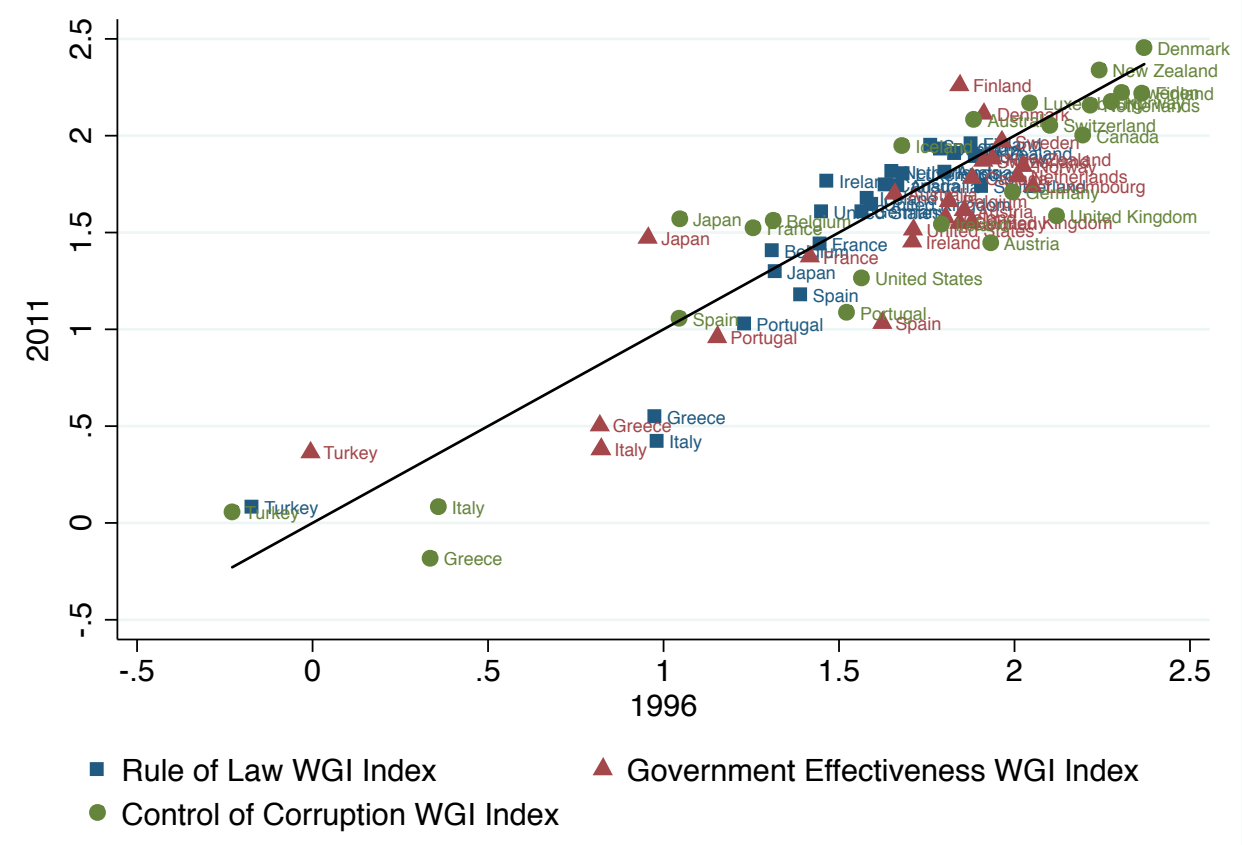

Figure 2 - WGI Indices 1996- 2011

\begin{tabular}{lccccc}
\hline \hline & $V A_{1996}=V A_{2011}$ & $G E_{1996}=G E_{2011}$ & $C C_{1996}=C C_{2011}$ & $P S_{1996}=P S_{2011}$ & $R L_{1996}=R L_{2011}$ \\
\hline Greece & $24.97 \%$ & $15.99 \%$ & $3.46 \%$ & $10.49 \%$ & $3.85 \%$ \\
Italy & $17.9 \%$ & $8.15 \%$ & $16.16 \%$ & $11.11 \%$ & $0.93 \%$ \\
Portugal & $4.77 \%$ & $26.95 \%$ & $6.44 \%$ & $12.94 \%$ & $19.96 \%$ \\
Spain & $16.67 \%$ & $3.12 \%$ & $51.13 \%$ & $38.90 \%$ & $18.58 \%$ \\
\hline \hline
\end{tabular}

Table 1 - Wald tests

This table reports probabilities that each variable's value in 1996 equals its value in 2011.

other indexes at least at the $20 \%$ level.

We stress that the magnitude and the likelihood of this institutional decline are specific to the four countries under consideration and have no analogue in the Euro area or even among OECD countries. To illustrate this point, Table 2 reports the results of a formal test of the evolution of institutional quality that allows to compare southern Europe with other countries, including those for whom the indexes of institutional quality show an constant or increasing trend. To be more specific, the table reports the probabilities that at least $n(=3,4,5)$ out of the 5 indexes of institutional quality have jointly increased over the 1996-2011 period. We run this test on southern European countries as well as on several Eurozone countries and (nonEurozone) Scandinavian countries. Overall, the probabilities that there was a joint increase in the quality of institution in southern Europe is at least one order of magnitude smaller than this probability for the other countries in the table. 


\begin{tabular}{lccc}
\hline \hline & At least 5 indexes & At least 4 indexes & At least 3 indexes \\
\hline Greece & $1.0 \mathrm{e}-3 \%$ & $6.9 \mathrm{e}-2 \%$ & $1.6 \%$ \\
Italy & $4.5 \mathrm{e}-3 \%$ & $0.19 \%$ & $3.2 \%$ \\
Spain & $9.2 \mathrm{e}-2 \%$ & $1.45 \%$ & $10.4 \%$ \\
Portugal & $1.9 \mathrm{e}-2 \%$ & $0.37 \%$ & $3.8 \%$ \\
\hline Belgium & $18.0 \%$ & $49.6 \%$ & $80.8 \%$ \\
France & $17.7 \%$ & $47.9 \%$ & $78.9 \%$ \\
Germany & $1.4 \%$ & $13.0 \%$ & $47.2 \%$ \\
Netherlands & $2.4 \%$ & $13.8 \%$ & $42.0 \%$ \\
\hline Denmark & $23.6 \%$ & $57.4 \%$ & $85.1 \%$ \\
Norway & $8.4 \%$ & $31.1 \%$ & $64.7 \%$ \\
Sweden & $20.1 \%$ & $54.0 \%$ & $85.1 \%$ \\
\hline \hline
\end{tabular}

Table 2 - Probabilities of increase of WGI indexes

This table reports probabilities that WGI indexes jointly increase during the 1996-2011 period.

\subsection{The role of capital inflows}

We now show that the countries that experienced a decline in the quality of their institutions where also those who benefited from capital inflows in the run-up to, and after the creation of, the Euro currency. Figure 3 plots the evolution of the ratio of current account to GDP from 1996 to 2011. Greece, Portugal, Spain and, to some extend, Italy stand out for the persistent capital inflows they have received during that period. ${ }^{7}$ The left panel of Figure 4 plots the change in the WGI Rule of Law index and the average Current Account-to-GDP ratio over the same period (1996 to 2011). Note that, by considering the average value of this ratio, we are focusing on the most persistent part of the current account during that period. The figure illustrates that countries which were receiving large capital inflows also experienced a decline in the quality of their institutions. Such a correlation also holds true for other measures of capital inflows or for the cost of borrowing faced by these countries. The right panel of Figure 4 plots changes in the real interest rate (the average of real interest rate in 1997-2011 minus the average in 1991-1996) against changes in the WGI Rule of Law index.

To summarize, the creation of the euro generated large capital inflows towards the periphery of Europe and allowed southern European countries to borrow at much cheaper interest rates. These persistent capital inflows were associated with a decline in the quality of domestic institutions.

\footnotetext{
${ }^{7}$ Note that Ireland also experienced a current account deficit during this period. However, when adjusted by FDI, incoming capital flows were negative. This is not the case of southern European countries. See the Appendix for details.
} 


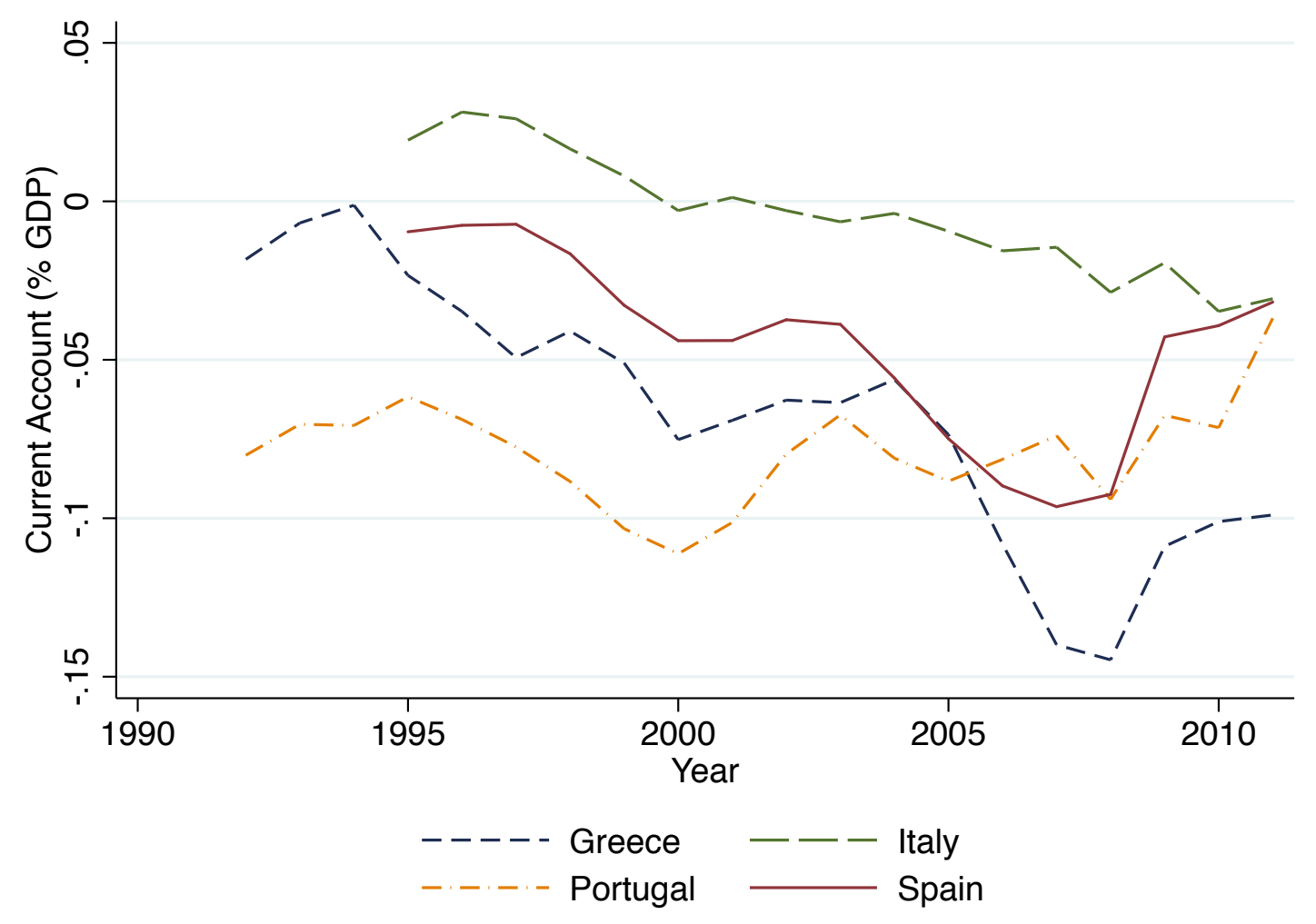

Figure 3 - Capital inflows - Current Account South Euro Members

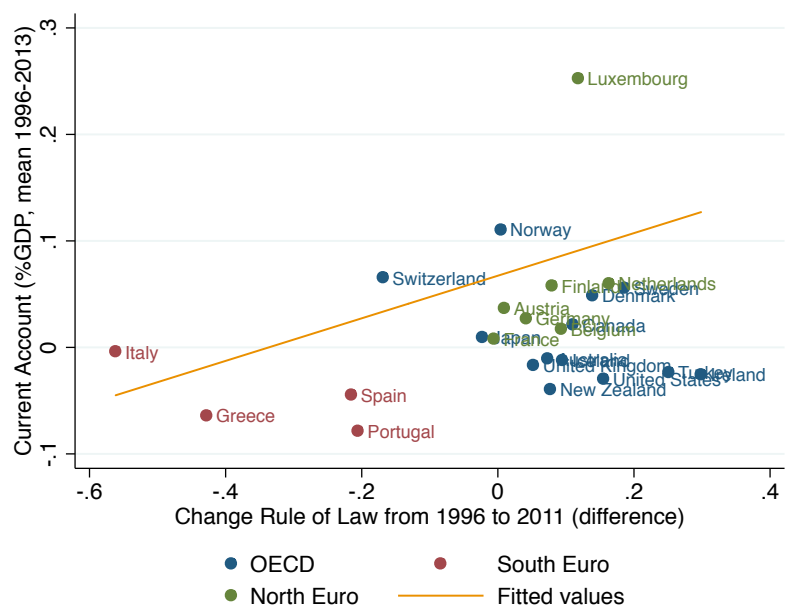

(a) Current Account

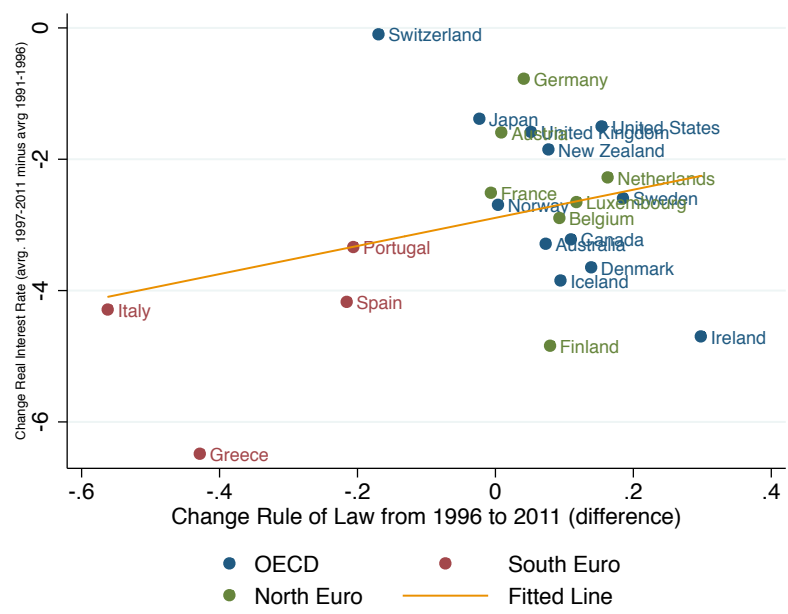

(b) Borrowing Costs

Figure 4 - Capital inflows and institutional quality 


\subsection{Anecdotal evidence of soft budget constraint syndrome.}

In the two previous subsections, we have documented a decline in the quality of institutions in the South of Europe, which, we argue, is connected to large and persistent capital inflows. Let us provide some more concrete examples of institutional failures in Southern Europe since the mid-1990s.

Spain. Ciudad Real International Airport, located 200 kilometers away from Madrid, was a private 1.5 -billion euros investment project initiated in the $2000 \mathrm{~s}$. It was able to welcome up to ten million passengers a year and its unique runaway was among the longest in Europe (so as to accommodate all airlines and planes, including the A380). The airport opened in 2008, but never hosted more than a twentieth of its capacity and welcomed its last flight in October 2011. Informed observers suspect that the project was never meant to be profitable but was expected to be bailed out by the regional government.

Portugal. In the 1990s and 2000s, Portugal promoted 15 public-private partnership (PPP) to modernize its road network, representing a total of 10 billion euro of private investment. The resulting concessions eventually gave rise to a major budgetary slippage, estimated to have cost the central government close to 1 billion euros by 2011 .

Greece. In 2004 Greece was home to the Olympic Games, after having won the bid over Rome. Unlike other cities, whose venues included prefabricated structures, Athens opted almost exclusively for heavy buildings, whose construction was contracted out to the private sector. Eventually the overall costs to the government (11 billion euros) was twice the projected cost. The Olympic sites now are a deserted apocalyptic landscape.

Italy. The airline company Alitalia reported net losses of more than 3.7 billion euros between 1999 and 2008; it was periodically refinanced by the Italian government over this period until the European Union forbid this support, forcing the company to privatize. ${ }^{8}$

Noticeably, all these examples are ones of "soft budget syndrome", where arguably negative NPV projects were undertaken on the basis of the expectation of later refinancing. In Section 3, we provide a formal model of this link: we interpret the quality of institutions as the ability of the government to implement a hard budget constraint, that is, to commit not to refinance

\footnotetext{
${ }^{8}$ Note that Italy experienced a period of "hard budget constraint" in the late 1980s and before the Euro, at least for publicly-run companies, as documented by Bertero and Rondi (2000). From this perspective, what we are documenting is a new period of softer budget constraint, taking a different form than of the 1980s since many state-owned companies got privatized in the 1990s.
} 
inefficient projects ex post. This commitment is costly, and therefore must outweigh the losses associated with refinancing inefficient projects. Cheap funding from abroad reduces the cost of not committing by making it easier to compensate the agents that would otherwise suffer from this lack of commitment; this reduces the government's incentives to commit, i.e., lowers the quality of institutions. ${ }^{9}$ To be more concrete, consider the case of a court that must decide upon liquidating a business. In the presence of cheap resources for the government, a poor decision that gives too much to the creditors or too much to the entrepreneur can be easily compensated by transfers in any form to the former or the latter. Hence, the incentives to make and implement a good decision in the first place is reduced.

\subsection{More general evidence of the link between institutions and capital flows}

We now investigate whether the link between capital inflows and degraded institutions holds more generally, and we confirm that it does.

Data description. To this purpose, we combine the WGI dataset with IFS data on Current Account (CA) as a fraction of GDP. The resulting combined dataset is an unbalanced panel with 188 countries from 1996 to 2013. We drop countries that, for the whole sample, exhibit a current account deficit or surplus higher than $10 \%$ as fraction of GDP. Those are mostly very small countries. We also drop countries that experienced a decline in GDP of more than $10 \%$ in one year as a result of a war or civil unrest (e.g. Libya, Rwanda or Iraq). After dropping these observations the dataset contains information about 102 countries.

Benchmark results. Table 3 presents the results. We find a positive and significant relationship between the Current-Account-to-GDP ratio and changes in the quality of institutions, as measured by the Rule of Law, even after controlling for GDP growth. ${ }^{10}$ Table 3 reports estimates for specifications including 2, 4, 6 and 8 years of past CA-to-GDP. We find that, for a horizon of 6 years or longer, the mean of past values of the CA-to-GDP ratio is positive and significant at explaining the Rule of Law. In contrast, shorter term current account deficits have a less significant effect on the quality of institutions. Such a finding suggests that persistent external deficits are necessary to effectively soften the government budget constraint

\footnotetext{
${ }^{9}$ Such a mechanism can be reinforced when capital inflows and low interest rates may lead to bailout expectations, as has been discussed in the context of the Euro area (see Mengus, 2015, for an analysis of implicit guarantees on debt and the resulting low level of interest rates).

${ }^{10}$ In the online appendix we also document the positive relationship between changes in TFP and WGI indicators for the same sample period and for a large sample of countries
} 
and affect institutional quality. These estimates control for country fixed effects that capture any country-specific explanation for changes in the quality of institutions, and allows us to focus on the common impact of capital inflows across countries. The GDP growth rate, which we use as a control variable, is positive but not statistically significant, which suggests that business cycle events such as economic crisis have limited effects on the quality of institutions. Finally, the fact that the lagged CA-to-GDP ratio remains significant after controlling for GDP growth suggests that the relationship between external financing and institutional quality is not explained by sudden stops in capital inflows or economic downturns.

Rent-seeking explanation of institutional declines. We report estimates for different sub-samples of the data. First, we exclude countries with high oil rents. Some of these countries, such as Venezuela, have seen the quality of their institutions deteriorating whilst having large, positive current account surpluses. In this case, the explanation for the institutional decline is not related to changes in external financing but rather by the rent-seeking or predatory behavior associated to high oil rents. When excluding these countries from our sample we find higher and more significant coefficients for the lagged values of current account to GDP ratios at the 4, 6 and 8-year horizons.

Non-linear effects of current account deficits. Second, we test whether the relationship between external financing and changes in the rule of law depends on the initial level of institutional quality. We find that the fixed-effect estimates after excluding countries with the lowest initial level of the rule of law (bottom quintile) are higher than before this exclusion. The same is true for the sample of non-oil dependent countries that excludes the top countries in terms of the initial level of the rule of law. Viewed through the lenses of the model that we propose below, these findings suggest that countries with the best institutions have low costs of maintaining them and are thus less susceptible to experience an institutional decline after large capital inflows. At the other end of the spectrum, the countries with the worst institutions have governments with very low ability to commit in the first place, which reduces the sensitivity of their incentives to capital inflows.

Figure 5 plots the relationship between changes in the Rule of Law and the mean of the CA-to-GDP ratio for the different sub-samples reported in Table 3. This graph illustrates the 


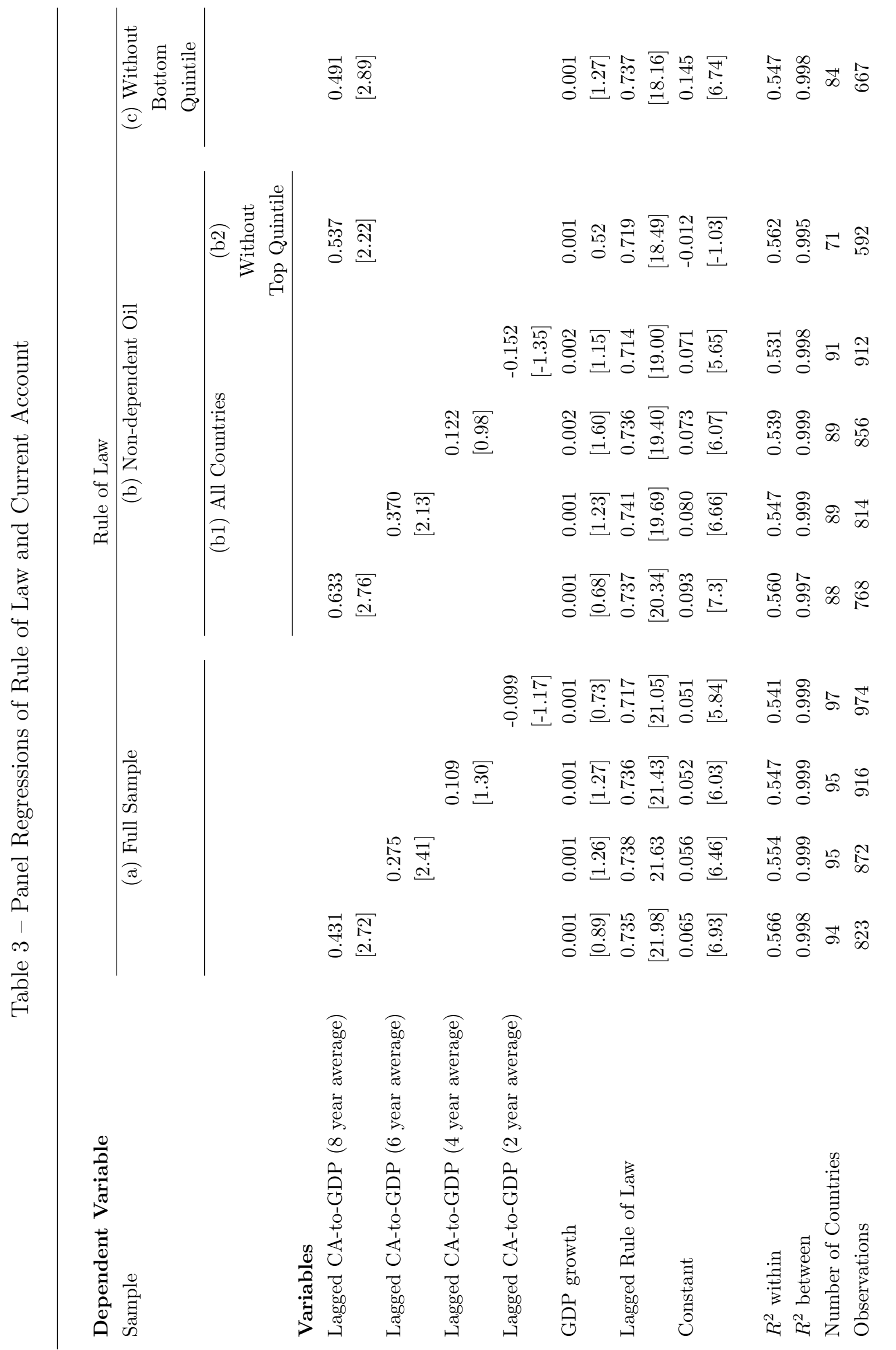

Ð

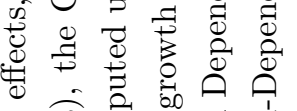

论

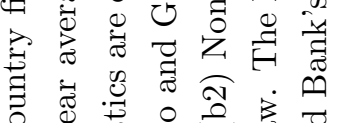

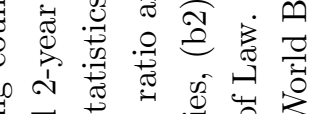

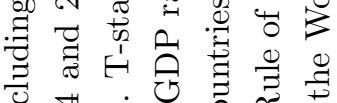

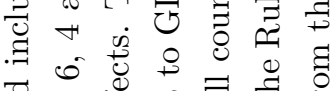

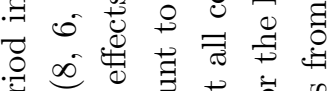

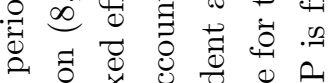

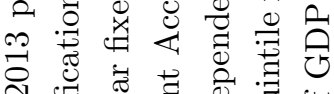

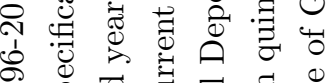

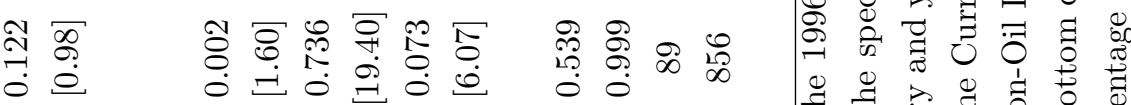

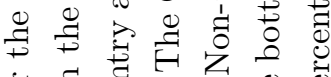

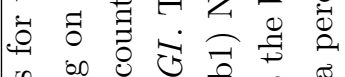

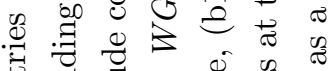

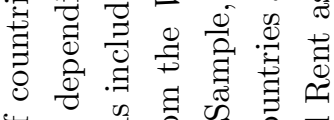

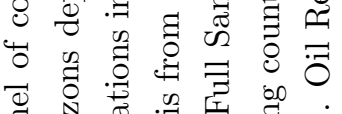

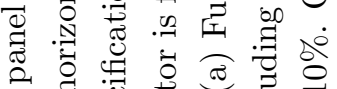

蒫

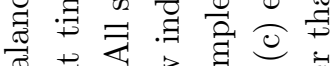

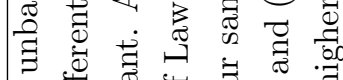

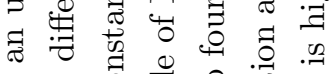

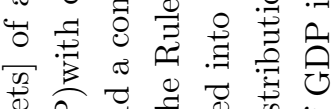

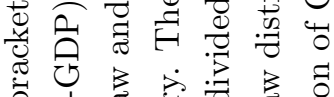

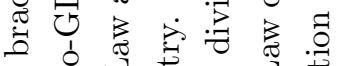

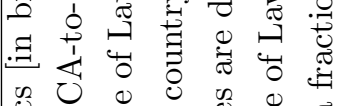

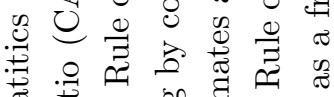

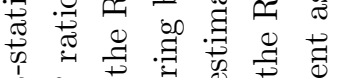

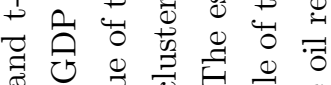

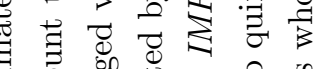

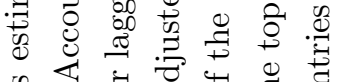

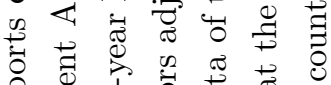

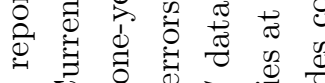

U O D W

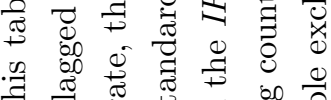

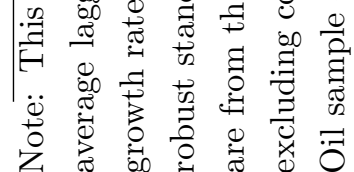


positive relationship between changes in the quality of institutions and external financing. In particular, it shows that non-oil economies for which the initial level of the Rule of Law index is neither too low nor too high exhibit a stronger relationship between external financing and variations in the quality of their institutions.

The case of the US and the UK. Let us now revisit this non-linearity within the subsample made of OECD countries. We already noted that Spain and Portugal experienced a somewhat milder effects of capital inflows on institutional quality relative to Italy and Greece, because their initial level of institutional quality was higher in the first place (see Figure 2). Figure 5d illustrates that some countries, e.g. the US, the UK, Iceland and Australia that were running a current account deficit during the period 1996-2011 did not subsequently experience a decline in the quality of their institutions (as measured by the Rule of Law index). Yet, when expanding the analysis to other WGI indexes, we can identify a mild institutional decline in the US and the UK. Table 4 reports p-values testing for the equality in WGI indexes between 1996 and 2011 and it shows that some indexes (e.g., Control of Corruption) have experienced a significant decline.

\begin{tabular}{cccccc}
\hline \hline & $V A_{1996}=V A_{2011}$ & $G E_{1996}=G E_{2011}$ & $C C_{1996}=C C_{2011}$ & $P S_{1996}=P S_{2011}$ & $R L_{1996}=R L_{2011}$ \\
\hline US & $17.95 \%$ & $26.43 \%$ & $12.75 \%$ & $29.25 \%$ & $74.11 \%$ \\
UK & $64.33 \%$ & $15.28 \%$ & $0.55 \%$ & $10.09 \%$ & $58.56 \%$ \\
\hline \hline
\end{tabular}

Table 4 - Wald tests

This table reports probabilities that each variable's value in 1996 equals its value in 2011.

As a robustness check, we report in Table 5 the probability of a joint increase in multiple WGI indexes for Southern European countries, the US and the UK as well as Denmark. These probabilities suggest that a joint decline of at least two indexes is likely at the $10 \%$ level both in the US and in the UK, but this decline was milder, less widespread across indexes and less significant than in the case of southern Europe.

In the next section we provide a theoretical framework, in the tradition of the "soft budget constraint" literature, which explicitly connects capital inflows and the quality of institutions. The key idea is that cheap borrowing from abroad undermines incentives to maintain good institutions, where "good" institutions are those that prevent the ex post refinancing of ex 


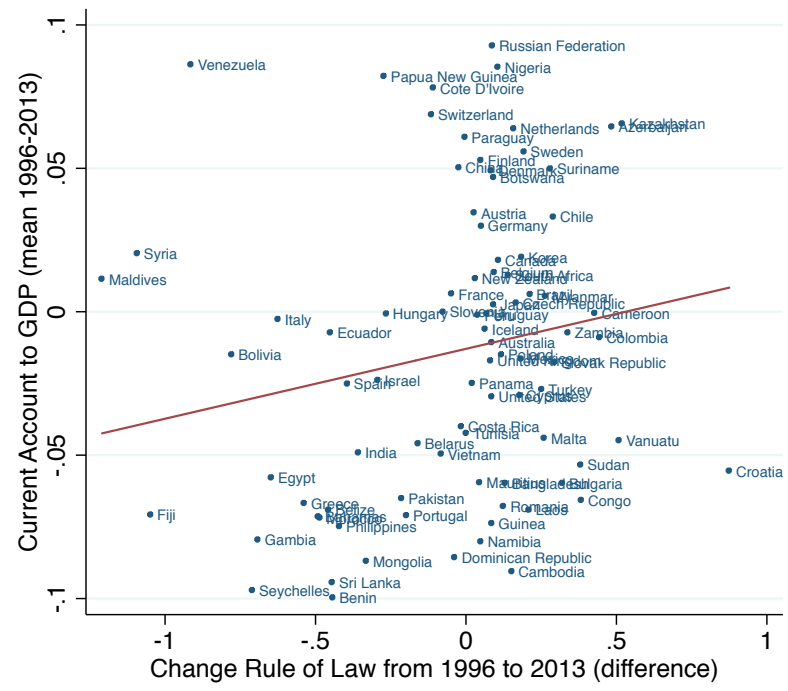

(a) Full Sample

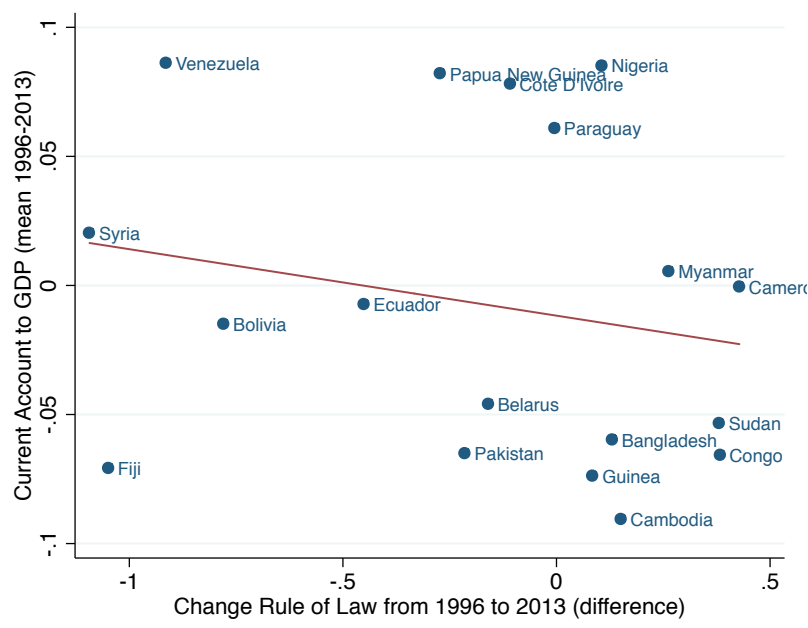

(c) Bottom Quintile Rule of Law

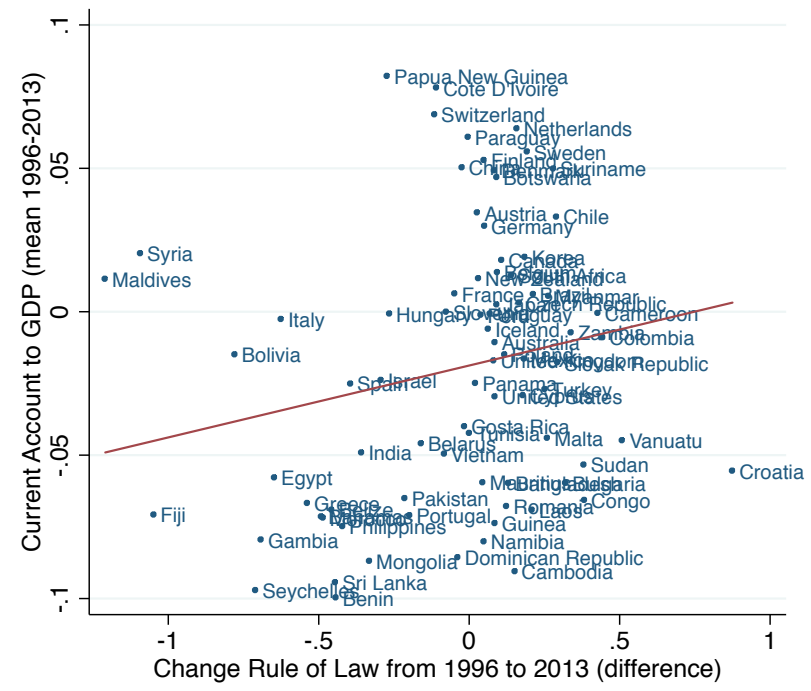

(b) Non-Oil Dependent

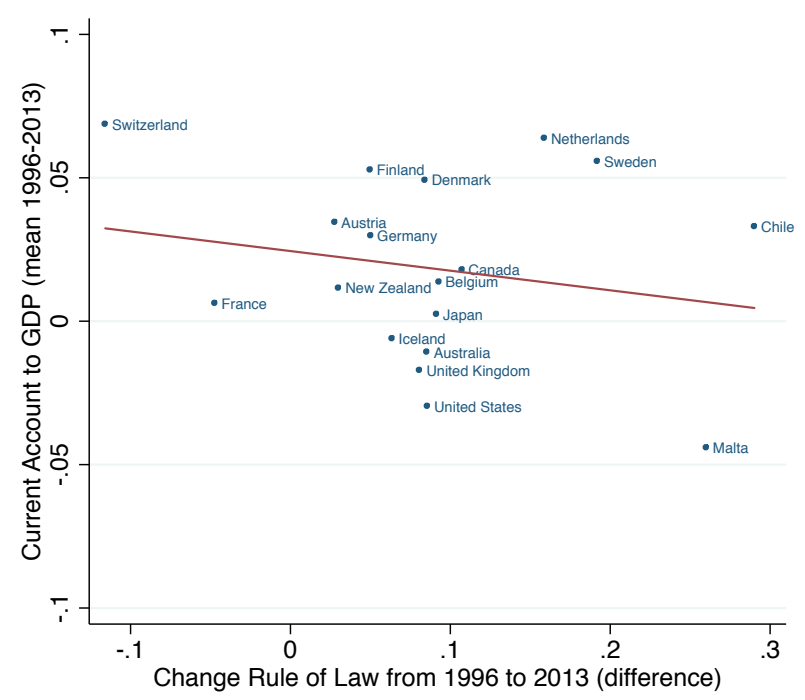

(d) Top Quintile Rule of Law

Figure 5 - Changes in the Rule of Law and External Financing: Cross-Sectional Evidence 


\begin{tabular}{ccccccccc}
\hline \hline & US & UK & Iceland & Denmark & Greece & Italy & Spain & Portugal \\
\hline At least 5 indexes: & $0.77 \%$ & $0.1 \%$ & $3.9 \%$ & $23.6 \%$ & $1.0 \mathrm{e}-3 \%$ & $4.5 \mathrm{e}-3 \%$ & $9.2 \mathrm{e}-2 \%$ & $1.9 \mathrm{e}-2 \%$ \\
At least 4 indexes: & $6.3 \%$ & $2.0 \%$ & $18.3 \%$ & $57.4 \%$ & $6.9 \mathrm{e}-2 \%$ & $0.19 \%$ & $1.45 \%$ & $0.37 \%$ \\
At least 3 indexes: & $26.3 \%$ & $16.1 \%$ & $47.6 \%$ & $85.1 \%$ & $1.6 \%$ & $3.2 \%$ & $10.4 \%$ & $3.8 \%$ \\
\hline \hline
\end{tabular}

Table 5 - Probabilities of increase of WGI indexes

This table reports probabilities that WGI indexes jointly increase during the 1996-2011 period.

ante inefficient projects.

\section{A model of capital inflows and deteriorating institu- tions}

In this section, we develop a model of the soft budget constraint that shows how the ease with which an economy can resort to foreign borrowing may deter the government's incentives not to refinance inefficient firms. The key assumption for our results is the government's inability to commit to future policies, namely, to commit not to compensate private agents for the costs of operating under weak economic institutions. We also derive some implications of our model as to the distribution of productivity among domestic firms, and relate those implications to the data in the following Section.

\subsection{Model description}

Time is discrete and indexed by $t \in\{0,1,2\}$. The economy is populated by domestic entrepreneurs, domestic investors, foreign investors and a government. There is only one homogeneous good.

Domestic entrepreneurs. A continuum of mass 1 of domestic entrepreneurs are endowed with projects in period 0 . With probability $\alpha$, the project is good. Otherwise, it is bad. Domestic entrepreneurs can decide whether to submit their projects for funding. The type of the project is private information to the entrepreneur.

With $i$ units of good invested in period 0, a good project yields a verifiable return $R^{g} i$ and a private benefit to the entrepreneur $B^{g} i$ in period 2. In contrast a bad project pays 
off in period 2 if only if an amount $j \leq i$ is reinvested in that period. In this case, it yields a verifiable return $R^{p} j$ and a private benefit $B^{p} j$ to the entrepreneur in period 2. If no reinvestment occurs, the project is liquidated in period 1 , yielding $R^{l} i$ to the investors and $B^{l} i$ to the entrepreneur. The latter private benefit is such that:

Assumption 1. $B^{l}<0$.

In addition, we assume that bad projects have negative NPV:

Assumption 2. $0>R_{p}+B_{p}-2$.

Domestic investors. Domestic investors are endowed with 1 unit of good in period 0 . They can invest in domestic entrepreneurs' projects. To this purpose, they can both borrow from foreign investors and invest their own money. Yet, their are borrowing-constrained and can only pledge a fraction $\rho$ of their future income. ${ }^{11}$

Foreign investors. Foreign investors are risk-neutral and value consumption at both dates. They are endowed with a large amount of goods in period 0 and can lend to the domestic government as well as to the domestic investors. They also have access to an outside constantreturns-to-scale investment opportunity that yields $1+r$ units of goods in period 1 for 1 unit of goods invested in period 0. This investment opportunity is infinitely supplied. Such an investment opportunity pins down the real interest rate required by foreign investors.

The government. The government can raise funds in period 2 and it can borrow from investors in period 1 and period 0 . In period 2 , it can reimburse $E$. In period 1 , it can make transfers to entrepreneurs and to domestic investors. Transfers to entrepreneurs are used to reinvest in projects $(j)$ and transfers to domestic investors are defined as a fraction $\eta$ of the proceeds of reinvestment, so that domestic investors receive a transfer $\eta R^{p}$ from the government in period 1.

Assumption 3. The government cannot commit not to implement transfers in period 1.

\footnotetext{
${ }^{11}$ The form of the borrowing constraint is simply assumed here, but it can easily be given proper microfoundations based on moral hazard.
} 
Commitment solution. Suppose that the government commits not to step in in period 1 $(j=0)$. As a result, no bad project are submitted by entrepreneurs and funded by domestic investors. Aggregate productivity is then $R^{g}$.

\subsection{Equilibrium description}

In this subsection, we describe the equilibrium of our model. To this purpose, we proceed backwards, starting from the government decision at date- 1 and, then, given this decision, we infer date-0 private agents' choices. From now on, we assume that the government cannot commit not to intervene in period 1.

Period 1. Let us describe the date-1 government decision. The government can decide to refund bad projects at a scale $j$ (no greater than the initial scale $i$ by assumption), and can also compensate domestic investors at an endogenous rate $\eta$. Crucially, the government has two options for raising funds to reinvest in projects and compensate investors: it can either raise taxes or issue debt. The government thus solves the following problem:

$$
\max _{j \leq i, 0 \leq \eta \leq 1} \max _{T^{1}+T^{2}=j+\eta R^{p}}\left(j\left(R^{p}+B^{p}\right)+\eta R^{p}-T^{1}-T^{2} \beta(1+r)\right)+1_{j=0}\left(R^{l}+B^{l}\right) i .
$$

The decision about how to finance reinvestment and compensation hinges on the relative costs of taxes and debt. Issuing debt requires paying an interest to creditors but delays the collection of taxes, so the discounted marginal cost of raising one unit of resources through debt is $\beta(1+r)$. In contrast, the marginal cost of funds raised through current taxes is 1 . As a result the government finances its expenses through debt if and only if $\beta(1+r)<1$.

The decision to refinance bad projects depends on the future marginal gain of reinvestment, $\left(R^{p}+B^{p}\right)$, the cost of reinvestment (which depends on how the reinvestment is financed), and the opportunity cost of not reinvesting, $\left(R^{l}+B^{l}\right)$. Finally, the decision to compensate domestic investors (i.e., the choice of $\eta$ ) must weigh the gain from doing so (as measured by investors' marginal utility of consumption) and the cost, which again depends on how this intervention is financed. The following proposition summarizes the government ex post decision (at date 1): 
Proposition 1. When the interest rate satisfies $\beta(1+r) \leq 1$ :

- compensation is optimally financed by debt: $T^{1}=0$ and $T^{2}=j+\eta R^{j}$;

- the government either reinvests at full scale $(j=i)$ or does not reinvest at all (so that the project is liquidated). Reinvestment takes place if and only if:

$$
1+r \leq 1+\bar{r}=\beta^{-1}\left[R^{p}-R^{l}+B^{p}-B^{l}\right]
$$

- the government compensates domestic investors at full scale: $\eta=1$.

When the interest rate satisfies $\beta(1+r)<1$,

- compensation is optimally financed by taxes: $T^{1}=j+\eta R^{j}$ and $T^{2}=0$;

- the government either reinvests at full scale $(j=i)$ or does not reinvest at all, and it does reinvest if and only if:

$$
R^{p}+B^{p}-1 \geq R^{l}+B^{l}
$$

- the government does not compensate domestic investors: $\eta=0$.

The government's assistance thus depends on its borrowing cost in period 1. When this borrowing cost is sufficiently low, the government is better off reinvesting in private agents' projects using borrowed funds. When borrowing costs are high, the government prefers to fund its assistance through current taxes. This also holds true for transfers to domestic investors : the cheaper the borrowing cost, the more likely they are compensated.

For the rest of the paper, we assume the following:

Assumption 4. Tax-financed transfers are not desirable:

$$
R^{p}+B^{p}-1 \leq R^{l}+B^{l} .
$$


Under such an assumption, we obtain the following corollary:

Corollary 2. The government provides assistance to bad projects if and only if

$$
1+r \leq 1+\bar{r}=\beta^{-1}\left[R^{p}-R^{l}+B^{p}-B^{l}\right]
$$

Proof. From Assumption 4, $R^{p}-R^{l}+B^{p}-B^{l} \leq 1$, hence condition 5 is equivalent to $(1+r) \beta \leq 1$

Period 0. We now turn to private agents' decisions in period 0 (i.e., entrepreneurs' decision to submit projects for funding and domestic investors' decisions to invest), given date 1 outcomes.

Project submission. Entrepreneurs endowed with good projects are always better off submitting them for funding, as their private benefits are positive $\left(B^{g}>0\right)$. Entrepreneurs endowed with bad projects receive a positive private benefit if their project is rescued in period $1\left(B^{p}>0\right)$ but a negative one if it is not rescued $\left(B^{l}<0\right)$. Hence, they submit their projects for funding only if they anticipate to be rescued by the government.

Domestic investors. Domestic investors choose the level of investment that maximizes their profits, subject to the borrowing constraint that they are facing. Formally, they solve the following problem:

$$
\begin{gathered}
\max _{i}\left(\hat{\alpha} R^{g}+(1-\hat{\alpha}) \eta R^{p} \frac{j}{i}\right) i-(1+r)(i-1) \\
\text { s.t. }(1+r)(i-1) \leq \rho i .
\end{gathered}
$$

As a result, when the marginal profit with respect to investment is sufficiently large, that is, whenever

$$
\hat{\alpha} R^{g}+(1-\hat{\alpha}) \eta R^{p} \frac{j}{i} \geq 1+r
$$

then domestic investors invest all their endowment and borrow up to the borrowing constraint. 
Investment then equals:

$$
i=\frac{1+r}{1+r-\rho}
$$

Note that the funding of bad projects does not crowd out the funding of good projects, except in the extreme situation where the number of bad projects is so large that it shuts down the funding of "all" projects. The reason for this lack of crowding out it that, when funding bad projects, domestic entrepreneurs increase their pledgeable income and, thus, their borrowing capacity.

Date-0 equilibrium. We can now analyse the date-0 equilibrium as a function of the country's current and expected borrowing costs. To this purpose, let us first define an equilibrium of our economy. Such an equilibrium is a set of choices and outcomes such that:

- entrepreneurs' choices of submitting their projects for funding or not at date 0 maximises their expected utility, given their expectations of the government's date-1 refinancing and transfer policies;

- domestic investors' choices of investment and foreign borrowing maximises their expected utility, given their expectations of the government's date-1 refinancing and transfer policies;

- the government's refinancing and transfer policies at date 1 maximise domestic households' welfare.

We then have the following proposition:

Proposition 3 (Equilibrium). Suppose that $(1+r) \beta \leq 1$, then the unique equilibrium of the economy is as follows:

(i) In period 1, the government provides full-scale refinancing of bad projects $(j=i)$ and full-scale support to domestic investors $(\eta=1)$; 
(ii) In period 0, all bad projects are submitted for funding and the investment scale is:

$$
i=\frac{1+r}{1+r-\rho}
$$

Otherwise, when $(1+r) \beta>1$, then the unique equilibrium is such that the government provides no assistance at date $1(j=0$ and $\eta=0)$ and no bad projects are submitted for funding at date 0 .

The proposition makes clear that the equilibrium outcome crucially depends on the level of interest rate at which the government is expected to borrow -and hence to behave. When the real interest rate is less than domestic households' rate of time preference (so that $(1+r) \beta \leq 1$ ), then the government is expected to rescue bad projects, thereby providing incentives for entrepreneurs to submit these projects for funding "ex ante". When the real interest rate is above the rate of time preference (so that $(1+r) \beta>1$ ), a rescue becomes too costly for the government. As a result, entrepreneurs with bad projects do not submit them for funding in the first place (i.e., they expect the government budget constraint to be "hard", not soft).

Productivity. We now derive some implications of our model for the distribution of firm-level productivity. In the equilibrium without government rescue, the average $(\bar{R})$ and the dispersion $(\sigma(R))$ of productivities are, respectively:

$$
\bar{R}=R^{g} \text { and } \sigma(R)=0
$$

In contrast, in the equilibrium with government rescue, those moments are:

$$
\bar{R}=\alpha R^{g}<R^{g} \text { and } \sigma(R)=\alpha(1-\alpha)\left(R^{g}\right)^{2}>0
$$

We summarize these properties in the following corollary:

Corollary 4. When private agents expect a government rescue, average productivity is lower, and the dispersion of productivity is larger, than when they expect no rescue. 
The level of investment. The level of investment in the economy is determined by the borrowing constraint faced by domestic investors and is given by:

$$
i=\frac{1+r}{1+r-\rho}
$$

which also increases with the level of real interest rate. This leads to the following corollary:

Corollary 5. Aggregate investment is higher, despite the fact that average productivity is lower, when domestic households expect a government rescue.

\subsection{Ex ante interventions}

We now turn to the possibility of ex ante interventions by the government aimed at altering its incentives to rescue private agents ex post. We assume that the government has access to a technology that limits the quantity of projects that it will be tempted to bail out in period 1 , at some ex ante cost paid in period 0: this cost is $C(\gamma)$, where $\gamma \in[0,1]$ is the share of bad projects that are not submitted for funding. We interpret $\gamma$ as an index of institutional quality: the higher $\gamma$, the higher the quality of institutions, since the government can prevent a larger share of projects from being undertaken. We assume that $C$ is an increasing and convex function of $\gamma$, with $C(1)=\infty$. The cost $C(\gamma)$ may correspond not only to the actual pecuniary cost of setting up effective regulation agencies (in goods market competition, banking, etc), but also to the opportunity cost for policymakers of having adopted good institutions, namely the fact they reduce policymakers' discretionary powers (see Buera et al., 2011, for a discussion and the quantitative effects of such costs). Note that the technology for reducing the prevalence of bad projects leaves the number of good projects $(\alpha)$ unaffected.

A date 0 the government chooses the level of institutional quality that solves:

$$
\max _{\gamma}(1-\gamma)(1-\alpha)\left[\left(\left(R^{p}+B^{p}-1\right)-\beta(1+r)\right) i\right]+C(\gamma)
$$

and the resulting choice of $\gamma$ takes the number of bad projects in the economy with ex post rescue from $1-\alpha$ to $(1-\gamma)(1-\alpha)$. The optimal value of $\gamma$ is such that the marginal cost (per project) of reducing the total number of bad projects is equal to the marginal cost of 
letting bad projects be funded:

$$
-\left(\left(R^{p}+B^{p}-1\right)-\beta(1+r)\right) i=\frac{C^{\prime}(\gamma)}{1-\alpha}
$$

The left hand side of the latter equation is decreasing in $r$. This implies the following:

Proposition 6. Suppose that $\beta(1+r) \leq 1$. Then,

(i) The lower the real interest rate $r$, the lower the level of institutional quality $\gamma$;

(ii) The lower the real interest rate $r$, the lower average productivity but the greater the dispersion of firm-level productivities;

(iii) The quality of institutions, as measured by the share of bad projects:

$$
s=\frac{(1-\gamma)(1-\alpha)}{\alpha+(1-\gamma)(1-\alpha)}
$$

- decreases with the real interest rate $r$,

- but is constant when $\alpha=1$ or $\alpha=0$.

Proof. Points (i) and (ii) in the proposition directly follow from the government's first-order condition w.r.t. the choice of $\gamma$ and from the computation of the mean and variance of productivity. For point (iii), noting that the share of bad projects is:

$$
s=\frac{(1-\gamma)(1-\alpha)}{\alpha+(1-\gamma)(1-\alpha)}
$$

we find its derivative w.r.t. $r$ to be:

$$
\frac{\partial s}{\partial r}=\frac{-\gamma_{r}(1-\alpha) \alpha}{(\alpha+(1-\gamma)(1-\alpha))^{2}} \leq 0
$$

In particular, this derivative is 0 for $\alpha=0$ or $\alpha=1$.

To summarize, the cost of government's funding affects its ex ante choice of institutional quality, i.e. its willingness to reduce the inefficiencies generated by the funding of inefficient 
projects. Low institutional quality is in turn associated with high investment (i.e., high private foreign borrowing) but low average productivity and high productivity dispersion. In line with the evidence presented in Section 2.4, we interpret the extreme cases where $\alpha=1$ or $\alpha=0$ as situations where institutions are so good (or so bad) in the first place that the interest rate no longer affect the government's tradeoff as to the choice of institutional quality.

We have built a model in which lower real interest rates leading to large capital inflows are associated with a lower quality of institutions and, ultimately, lower average productivity. The key mechanism is that lower real interest rates increase the government's ability to bail out its residents, thus exacerbating soft budget constraints syndrome. Put differently, the soft budget constraint syndrome, and the aggregate inefficiency that results, are socially less costly when external funding is cheap; hence, the incentive to alleviate the syndrome by raising the quality of institutions is diminished.

\section{Institutional quality and total factor productivity}

As discussed above, our model predicts that low interest rates and easy borrowing lead to low institutional quality, and ultimately to low productivity and high productivity dispersion. In this section we focus on the implications of our model for productivity, and to this purpose examine the joint evolution of institutional quality and productivity both in the OECD countries and in the large sample of countries considered in Section 2.4. In line with earlier empirical studies, we confirm the reduction in the growth, if not a decline, in TFP in the south of Europe in the run-up to, and after the creation of, the Euro currency (hence long before the financial crisis). ${ }^{12}$ In line with our model, we do not find this decline to be concentrated in particular sectors such as the tradeables sector or sectors that that suffer from stronger credit market frictions. More generally, we document the systematic link between aggregate productivity and institutional quality in a broad sample of countries.

\footnotetext{
${ }^{12}$ Cette et al. (2015) and the references therein. Note that while these authors interpret the causal link they find going from low interest rates to low productivity in terms of capital misallocation, this link is equally consistent with an indirect causal effect working through the lower quality of economic institutions, as we emphazise in this paper.
} 


\subsection{A fall in the quality of institutions correlated with the decline in TFP}

We first document the decline in aggregate productivity growth in the south of Europe by running a OLS fixed-effect regressions testing whether there has been a change in the dynamics of TFP in European countries since the introduction of the Euro. More specifically, we estimate equation (14) using data from the Penn World Tables.

$$
\gamma_{i, t}^{T F P}=\alpha_{i}+\alpha_{t}+\delta_{\text {euromember }}+\delta_{\text {euro }}+\delta_{\text {eurocrisis }}+\delta_{\text {euro }} \times \delta_{\text {south }}+\delta_{\text {eurocrisis }} \times \delta_{\text {south }}+\epsilon_{i, t},
$$

where $\gamma_{i, t}^{T F P}$ denotes country i's TFP growth rate in period $t, \alpha_{i}$ and $\alpha_{t}$ are country and year fixed-effects and the $\delta$ s are dummies. We use a dummy for Euro members, a dummy for the period after the creation of the Euro up to 2007 for all European countries and only the South of Europe, and a dummy since the 2007 crisis for all European countries and only the North of Europe.

Table 6 - OLS Fixed-Effects Regressions of TFP in OECD Countries

\begin{tabular}{lccc} 
Variable & Coefficient & Standard Errors & P-Value \\
\hline Constant & 0.854 & 0.017 & 0.000 \\
Euro Member & -0.002 & 0.002 & 0.196 \\
Europe before Crisis & 0.002 & 0.001 & 0.052 \\
South Europe before Crisis & -0.003 & 0.001 & 0.012 \\
Crisis & -0.002 & 0.000 & 0.001 \\
& & & \\
No. of observations & 1,008 & & \\
$R^{2}$ within & 0.41 & & \\
$R^{2}$ between & 0.21 & & \\
\hline
\end{tabular}

Source: Author's Regressions. The dependent variables is the TFP growth rate. The first column reports OLS coefficients of a balanced panel of 24 OECD countries from 1970 to 2011 at yearly frequency with country and year fixed-effects. The second column reports the robust standard errors, adjusterd for clustering by country. The third column presents the respective p-values. South Europe corresponds to Spain, Portugal, Italy and Greece. North Europe is composed of Austria, Belgium, Finland, France, Germany, Luxembourg and Netherlands.

Table 6 reports the estimates for the level of TFP growth of a balanced panel of 24 OECD countries. All variables, with the exception of the dummy for Euro members, are significant at the $10 \%$ level. The average TFP growth rate for the sample is $0.5 \%$. For the whole sample of European countries the growth rate of TFP after the introduction of the Euro and before 


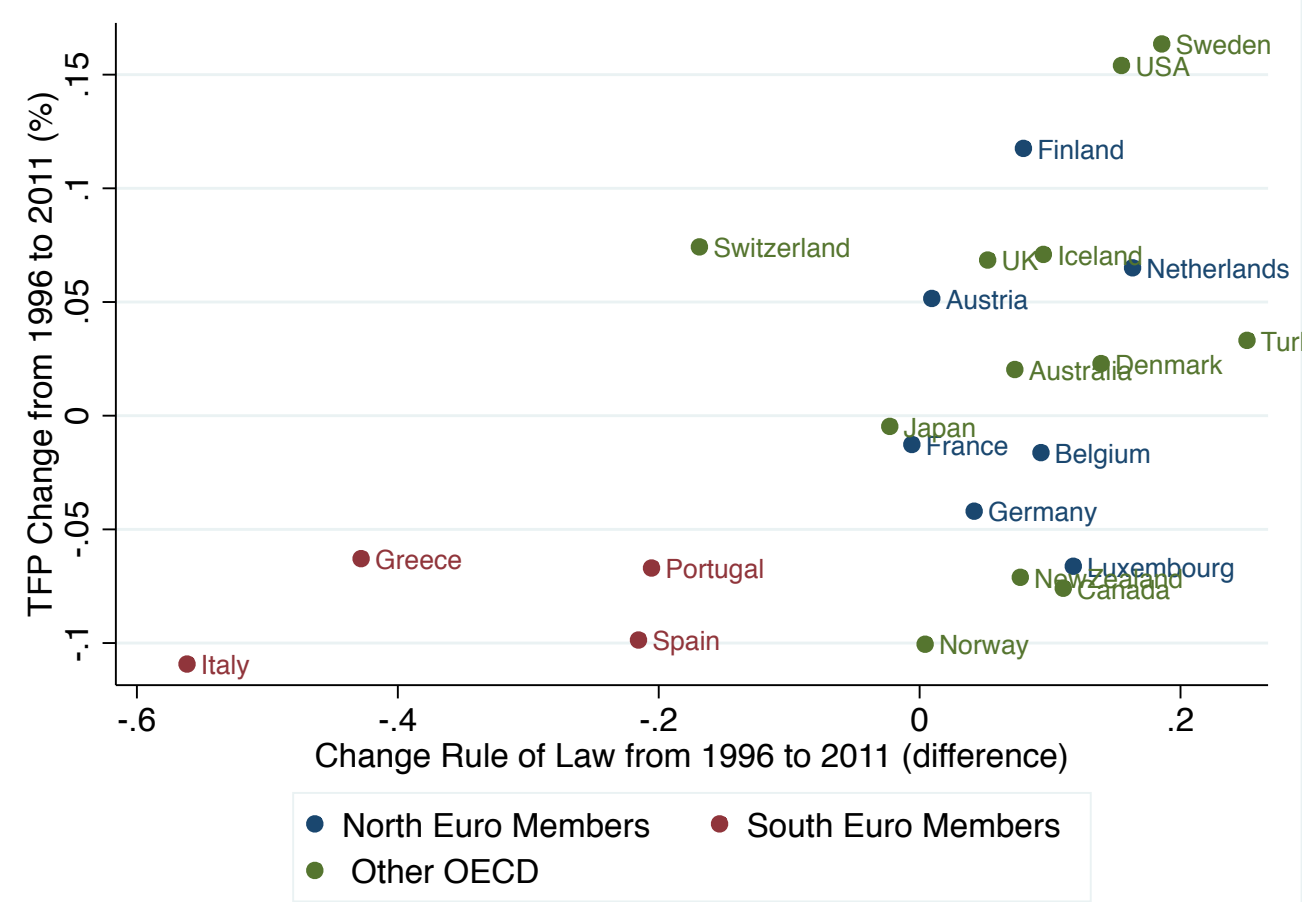

Figure 6 - TFP and Rule of Law Changes from 1996 to 2011 OECD

the crisis in 2007 increased by $0.2 \%$, but fell by $0.3 \%$ for the southern European countries. This decline in the TFP growth rate in South Europe is bigger than the fall in the same variable since the last crisis, which indicates the quantitative importance of the decline in TFP in southern Europe before the crisis. Alternative specifications for this regression are presented in the online appendix and confirm these results.

To illustrate the link between institutional quality and TFP growth, Figure 6 and 7 plot changes in the Rule of Law index and the cumulative change in TFP from 1996 to 2011, both in the OECD and in the large sample. Those figures make clear that there is a strong (negative) correlation between the two. This general pattern is striking in the case of southern Europe, where worsening institutional quality was associated with negative TFP changes.

\subsection{Further evidence}

The evidence presented above confirms that in earlier studies documenting the productivity slump of southern Europe over the past couple of decades. Our model naturally ties this slump to degraded institutions (as caused by the availability of cheap external funds). In what follows, we discuss the two main alternative (and potentially complementary) explanations 


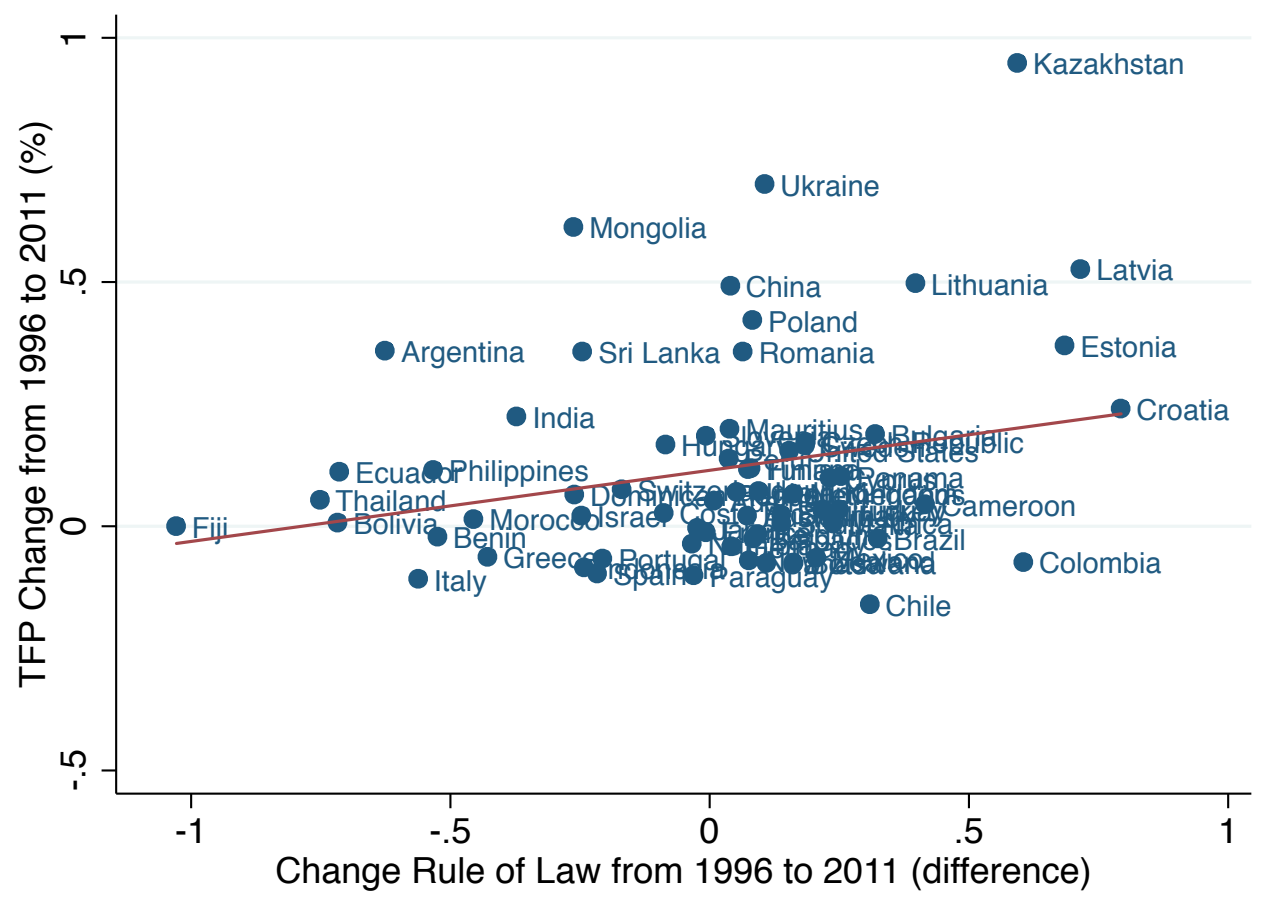

Figure 7 - TFP and Rule of Law Changes from 1996 to 2011 Large Sample

for southern Europe's productivity slowdown, namely factor misallocation (in capital input), and sectoral misallocation.

Capital misallocation. One leading explanation for the low level of TFP growth suffered by southern European countries since the mid-1990s, put forth by Gopinath et al. (2015), is capital misallocation. They show empirically that the low interest rates enjoyed by Southern European countries led to a widening in the dispersion of marginal returns to capital across firms and a fall in TFP; they then illustrate theoretically that this is the natural outcome of a model economy plagued by financing constraints directing capital inflows towards the larger, rather than most productive, firms. From a quantitative point of view, their model accounts for a quarter to a third of the observed shortfall in aggregate TFP in Spain when the model is calibrated to match the observed dispersion of marginal returns to capital across Spanish manufacturing firms. ${ }^{13}$ This suggests that the misallocation of capital is unlikely

\footnotetext{
${ }^{13}$ Gopinath et al. (2015) document a TFP shortfall of $12 \%$ in Spain (Figure 4) and their model is able to explain a decline up to 3 to $4 \%$ when matching the cross-sectional distribution of marginal productivity of capital (Figure 11).
} 


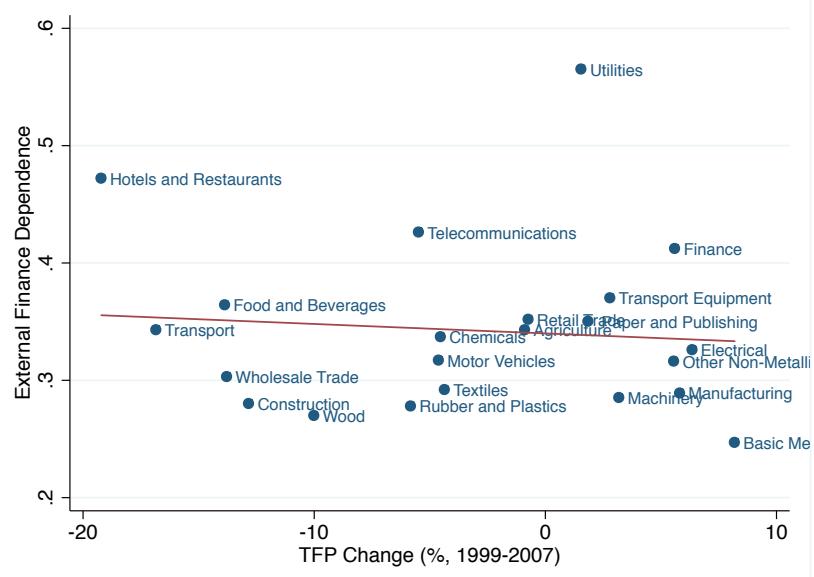

(a) Spain

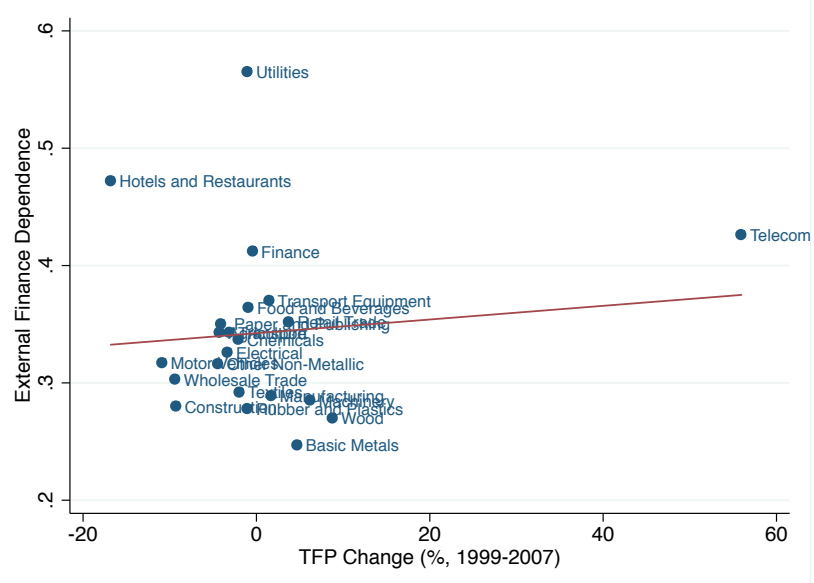

(c) Italy

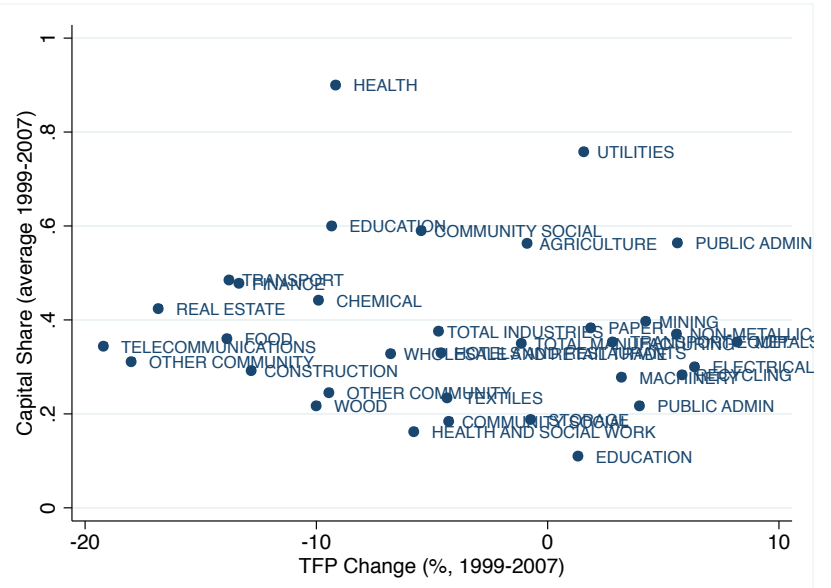

(b) Spain

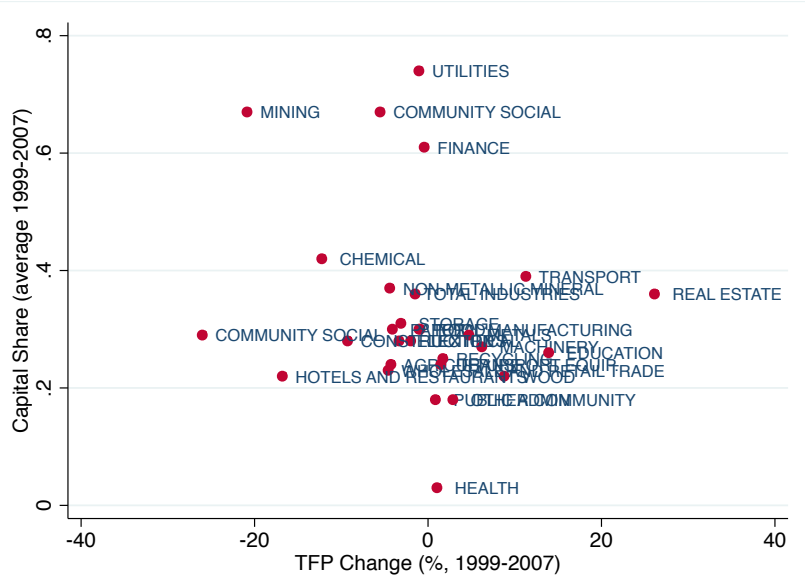

(d) Italy

Figure 8 - Sectorial TFP decline, External Finance Dependence and Capital Shares

to be the only cause of low TFP in Southern Europe in the 2000s; our paper emphasizes an additional link between capital inflows and low TFP growth, working through the deterioration of institutions.

To evaluate how capital frictions may affect productivity throughout the economy, Figure 8 plots the cumulative change in total factor productivity as a function of the financial dependence ratio and the average capital share for 34 disaggregated sectors in Spain and Italy. ${ }^{14}$ Note that in both countries there is no clear correlation between those variables and the TFP decline across sectors, in contrast to what Gopinath et al. (2015) have found within the Spanish manufacturing sector. While this finding does not invalidate explanations of the

\footnotetext{
${ }^{14}$ We take the financial dependence ratios for the EU Klems database from Inklaar et al. (2012) that are computed as in Inklaar and Koetter (2008). Note that we cannot directly use the Rajan and Zingales (1998)' computed values as the EU Klems database includes more sectors that are not in Rajan and Zingales (1998)' set of sectors.
} 
productivity slump based on capital misallocation, it requires this misallocation to happen exclusively within sectors, without having visible effects in the inter-sectoral allocation of capital. These results echoes Dias et al. (2015)'s findings that financial dependence is unrelated to TFP losses in Spain. ${ }^{15}$

Sectoral misallocation. Another type of capital misallocation that can arise after the opening to external capital flows is that occurring between sectors rather than across firms within the same sector. Benigno et al. (2015) study a large number of credit booms and show that they are systematically followed by a reallocation of factors away from the manufacturing sector and a protracted fall in GDP (Benigno et al., 2015). Kalantzis (2014) provides a quantitative model of the sectorial structure of a small open economy and uses it to study several credit booms leading to the over-expansion of non-tradables production. We note that in the case of southern Europe almost all sectors experienced low TFP growth in the period under consideration, so that sectorial misallocation cannot be the full story. Focusing on countryspecific experiences, Reis (2013) and Dias et al. (2015) also point out to factor misallocation as the key explanation for the low TFP growth in Portugal, whether this misallocation occurs between (Reis, 2013) or within (Dias et al., 2015) sectors. Similarly, Garcia-Santana et al. (2015) and Calligaris (2015) point out to within-industry factor misallocation in Spain and Italy, respectively, over the period under scrutiny. In order to evaluate whether the misallocation of resources was truly economywide (as our model implies) or sectoral, we run a similar regression as before but using TFP at the sectoral rather than economy-wide level, using the EU Klems database (O'Mahony and Timmer, 2009). Table 9 reports the estimates of an OLS fixed-effect regression of TFP for 8 different sectors of a sample of 15 OECD countries from 1980 to 2007. The table confirms that the productivity slump in southern Europe is an econmywide phenomenon (with the notable exception of the finance sector) and is not driven by specific sectors like the tradeables. Figure 9 shows the change of TFP in Spain and Italy between 1999 and 2007 in a more disaggregated breakdown that comprises 16 sectors. The same pattern emerges of a productivity decline across most of the spectrum of economic

\footnotetext{
${ }^{15}$ Dias et al. (2015) also dismiss explanations based on skill intensity or innovative content and they emphasize within-sector misallocation of production factors for Spain. Our evidence for Italy draws a similar picture.
} 


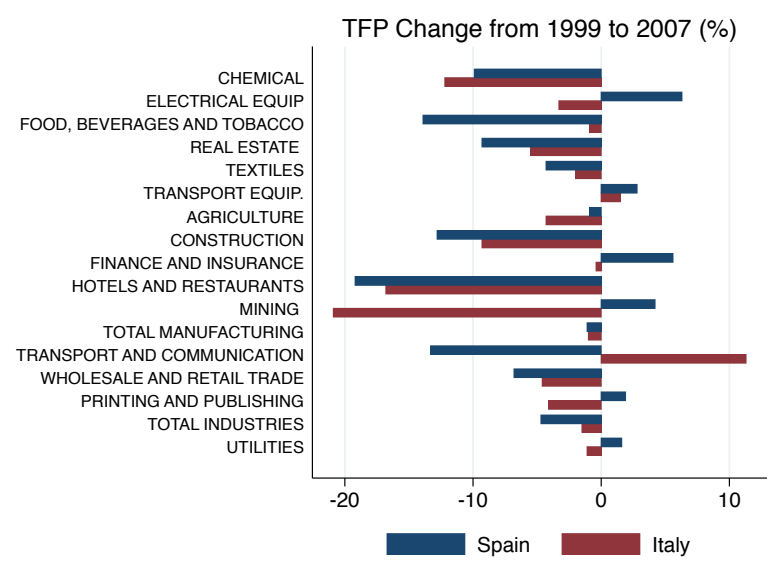

Figure 9 - Sectorial TFP growth in Italy and Spain

activities. $^{16}$ This is precisely what one would expect from a productivity slump driven by degraded economic institutions.

\section{Conclusion}

In this paper, we have documented a decline in the quality of institutions in the South of Europe (Greece, Italy, Spain and Portugal), that was correlated with negative productivity growth and current account deficits. We then build a model of soft budget constraints that can account for such a correlation: cheaper borrowing due to capital inflows reduces the need to maintain good institutions and, in turn, this decreases the average productivity of projects run in the economy. Finally, we have also confirmed the relation between current account deficits or capital inflows and the quality of institutions on a large panel of countries.

\footnotetext{
${ }^{16}$ The same argument challenges the view that the decline in productivity in southern Europe is explained by lack of innovation in the face of stronger competition from China, as suggested by Pellegrino and Zingales (2014). Productivity in non-tradable sectors decline as much as or in some cases even more than in tradable sectors. This is the case, for example, of the hotels and restaurant sector that experience a decline in productivity of almost 20\% since Spain and Italy joined the Euro and the beginning of the 2008 crises.
} 


\section{References}

Acemoglu, D. (2009): Introduction to Modern Economic Growth, Princeton University Press.

Acemoglu, D., S. Johnson, And J. Robinson (2003): "Botswana: an African success story," In Search of Prosperity. Princeton University Press, Princeton, New Jersey, 80-119.

Acemoglu, D. And J. Robinson (2012): Why Nations Fail, Crown Publishing Group.

Acemoglu, D. And M. Ucer (2015): "The Ups and Downs of Turkish Growth, 2002-2015: Political Dynamics, The European Union and the Institutional Side," Working Paper 21608, National Bureau of Economic Research.

Acemoglu, D., T. Verdier, And J. A. Robinson (2004): "Kleptocracy and divideand-rule: A model of personal rule," Journal of the European Economic Association, 2, $162-192$.

Benigno, G., N. Converse, And L. Fornaro (2015): "Large capital inflows, sectoral allocation, and economic performance," Journal of International Money and Finance, 55, $60-87$.

Bertero, E. And L. Rondi (2000): "Financial pressure and the behaviour of public enterprises under soft and hard budget constraints: evidence from Italian panel data," Journal of Public Economics, 75, 73-98.

Buera, F. J., A. Monge-Naranjo, And G. E. Primiceri (2011): "Learning the Wealth of Nations," Econometrica, 79, 1-45.

Calligaris, S. (2015): "Misallocation and Total Factor Productivity in Italy: Evidence from Firm-Level Data," Working Paper 13(9)-357, CEIS Tor Vergata.

Cette, G., J. Fernald, And B. Mojon (2015): "The Pre-Global-Financial-Crisis Slowdown in Productivity," Working paper. 
Dewhtripont, M. And E. MASkin (1995): "Credit and efficiency in centralized and decentralized economies," Review of Economic Studies, 62, 541-556.

Di Tella, R. And A. Ades (1999): "Rents, Competition, and Corruption," American Economic Review, 89, 982-993.

Dias, D. A., C. R. Marques, And C. Richmond (2015): "Misallocation and Productivity in the Lead Up to the Eurozone Crisis," Working Paper 1146, Board of Governors of the Federal Reserve System International Finance Discussion Papers.

FARHi, E. AND J. Tirole (2012): "Collective Moral Hazard, Maturity Mismatch, and Systemic Bailouts," American Economic Review, 102, 60-93.

Garcia-Santana, M., E. Moral-Benito, J. Pijoan-Mas, and R. Ramos (2015): "Growing like Spain: 1995-2007," Tech. rep.

Gopinath, G., S. Kalemli-Ozcan, L. Karabarbounis, and C. Villegas-Sanchez (2015): "Capital Allocation and Productivity in South Europe," Tech. rep., National Bureau of Economic Research.

Hall, R. E. And C. I. Jones (1999): "Why Do Some Countries Produce So Much More Output Per Worker Than Others?" Quarterly Journal of Economics, 114, 83-116.

InklaAR, R. AND M. Koetter (2008): "Financial dependence and industry growth in Europe: Better banks and higher productivity," GGDC Research Memorandum GD-100, Groningen Growth and Development Centre, University of Groningen.

InklaAr, R., M. Koetter, And F. Noth (2012): "Who's afraid of big bad banks? Bank competition, SME, and industry growth," Frankfurt school - working paper series, Frankfurt School of Finance and Management.

KalantzIs, Y. (2014): "Financial fragility in small open economies: firm balance sheets and the sectoral structure," Working papers 505, Banque de France. 
Kaufmann, D., A. KraAy, And M. Mastruzzi (2010): "The worldwide governance indicators : methodology and analytical issues," Policy Research Working Paper Series 5430, The World Bank.

Kornai, J. (1979): Economics of shortage, North-Holland.

Kornai, J., E. Maskin, And G. Roland (2003): "Understanding the Soft Budget Constraint," Journal of Economic Literature, 41, 1095-1136.

Lane, P. R. And A. Tornell (1996): "Power, growth, and the voracity effect," Journal of Economic Growth, 1, 213-241.

MAskin, E. S. (1996): "Theories of the soft budget-constraint," Japan and the World Economy, 8, 125-133.

Mehlum, H., K. Moene, And R. Torvik (2006): "Institutions and the resource curse*," The economic journal, 116, 1-20.

Mengus, E. (2015): "Asset Purchases Bailouts and Implicit Guarantees," Mimeo.

North, D. C. (1991): "Institutions," Journal of Economic Perspectives, 5, 97-112.

O’Mahony, M. And M. P. Timmer (2009): "Output, Input and Productivity Measures at the Industry Level: The EU KLEMS Database," Economic Journal, 119, F374-F403.

Pellegrino, B. And L. Zingales (2014): "Diagnosing the Italian disease," Unpublished manuscript, September.

Rajan, R. G. And L. Zingales (1998): "Financial Dependence and Growth," American Economic Review, 88, 559-86.

REIs, R. (2013): "The Portuguese Slump and Crash and the Euro Crisis," Brookings Papers on Economic Activity, 143.

Robinson, J. A., R. Torvik, And T. Verdier (2006): "Political foundations of the resource curse," Journal of development Economics, 79, 447-468. 
Sachs, J. D. And A. M. Warner (1995): "Natural Resource Abundance and Economic Growth," NBER Working Paper Series, 5398.

Tornell, A. And P. R. Lane (1999): "The Voracity Effect," American Economic Review, $89,22-46$. 


\section{A World Governance Indicators.}

In this appendix, we provide some further elements on the World Governance Indicators as well as robustness checks for the decrease in institutional quality in the periphery of Europe.

Data sources. The WGI indicators are based on "expert" or survey-based indicators. We list here all these databases.

"Expert" sources. These include: African Development Bank Country Policy and Institutional Assessments (GOV), Asian Development Bank Country Policy and Institutional Assessments (GOV), Bertelsmann Transformation (NGO), Freedom House Countries at the Crossroads (NGO), Global Insight Global Risk Service (CBIP), European Bank for Reconstruction and Development Transition Report (GOV), Economist Intelligence Unit Riskwire \& Democracy Index (CBIP), Freedom House (NGO), Global Integrity Index (NGO), Heritage Foundation Index of Economic Freedom (NGO), Cingranelli Richards Human Rights Database and Political Terror Scale (GOV), IFAD Rural Sector Performance Assessments (GOV), JET Country Security Risk Ratings (CBIP), Institutional Profiles Database (GOV), IREEP African Electoral Index (NGO), International Research and Exchanges Board Media Sustainability Index (NGO), International Budget Project Open Budget Index (NGO), World Bank Country Policy and Institutional Assessments (GOV), Political Risk Services International Country Risk Guide (CBIP), Reporters Without Borders Press Freedom Index (NGO), US State Department Trafficking in People report (GOV), Yearbook Global Insight Business Conditions and Risk Indicators (CBIP).

CBIP stands for Commercial Business Information Provider, GOV for Public Sector Data Provider and NGO for Nongovernmental Organization Data Provider.

Surveys. These include: Afrobarometer, Business Enterprise Environment Survey, Transparency International Global Corruption Barometer Survey, World Economic Forum Global Competitiveness Report, Gallup World Poll, Latinobarometro, Political Economic Risk Consultancy Corruption in Asia Survey, Vanderbilt University Americas Barometer, Institute for Management and Development World Competitiveness.

Quantifying the trend. Table 7 gathers the results of the following regression:

$$
Y_{i, t}=\alpha_{i}+\left(\text { Trend }+\delta_{i} \text { PeriTrend }\right) t+\epsilon_{i, t}
$$

with $\delta_{i}=1$ for Greece, Italy, Portugal and Spain and 0, otherwise, and where $Y$ is one of the six measures of institutional quality: voice and accountability, government effectiveness, control of corruption, Political stability, rule of law and regulatory quality. The general outcome is that, for all variables, the trend in the periphery is significantly negative. 


\begin{tabular}{lcccccc}
\hline \hline & V.A. & G.E. & C.C. & P.S. & R.L. & R.Q. \\
Trend & $.0007(.0012)$ & $-.0138(.0023)$ & $-.0036(.0022)$ & $-.0109(.0019)$ & $.0054(.0010)$ & $.0064(.0019)$ \\
Peri. trend & $-.0248(.0028)$ & $-.0339(.0056)$ & $-.0426(.0053)$ & $-.0252(.0047)$ & $-.0333(.0023)$ & -.0277 .0046 \\
\hline$R^{2}$ & .0769 & .2642 & .3154 & .1274 & .2183 & .3045 \\
\hline \hline
\end{tabular}

Table 7 - Institutional decay

Robustness with underlying series. Indicators are aggregates of data coming from multiple sources, and their composition may evolve over time. In this paragraph, we check that the trends observed on aggregates also hold for most of the indicators' components.

\begin{tabular}{lccccc}
\hline \hline & VA & PS & GE & RL & CC \\
\hline Greece & $6 / 2$ & $5 / 1$ & $4 / 1$ & $5 / 2$ & $5 / 0$ \\
Italy & $5 / 3$ & $4 / 2$ & $5 / 0$ & $6 / 2$ & $4 / 1$ \\
Portugal & $8 / 0$ & $4 / 2$ & $3 / 2$ & $7 / 1$ & $1 / 4$ \\
Spain & $7 / 1$ & $4 / 2$ & $4 / 1$ & $5 / 2$ & $4 / 1$ \\
\hline \hline
\end{tabular}

Table 8 - Number of decreasing / increasing underlying series.

This table reports the number of decreasing and increasing series underlying each indicator and that are available at least from 2002 onwards. The first number indicates the number of decreasing series and the second one the number of increasing series.

Table 8 reports how the series underlying each governance indicators evolve over time. For almost all indicators and for all countries, more than two thirds of the series have a downward trend, thus confirming the aggregate behavior that we have identified. There is only one exception: control of corruption in Portugal. In this case, three of the increasing underlying series are in fact close to be constant. 


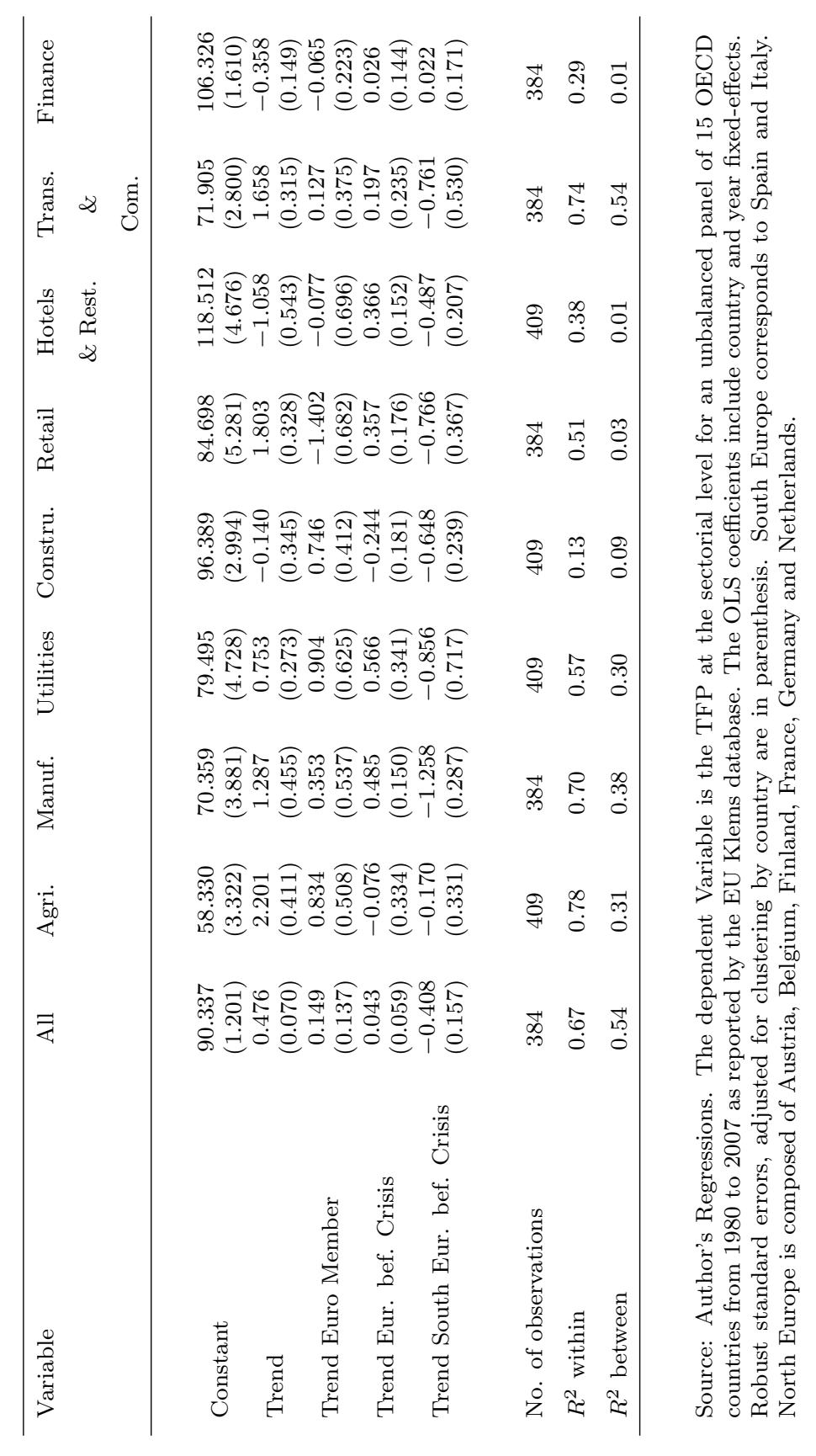

Table 9 - OLS Fixed-Effects Regressions of TFP level at the Sectorial level 

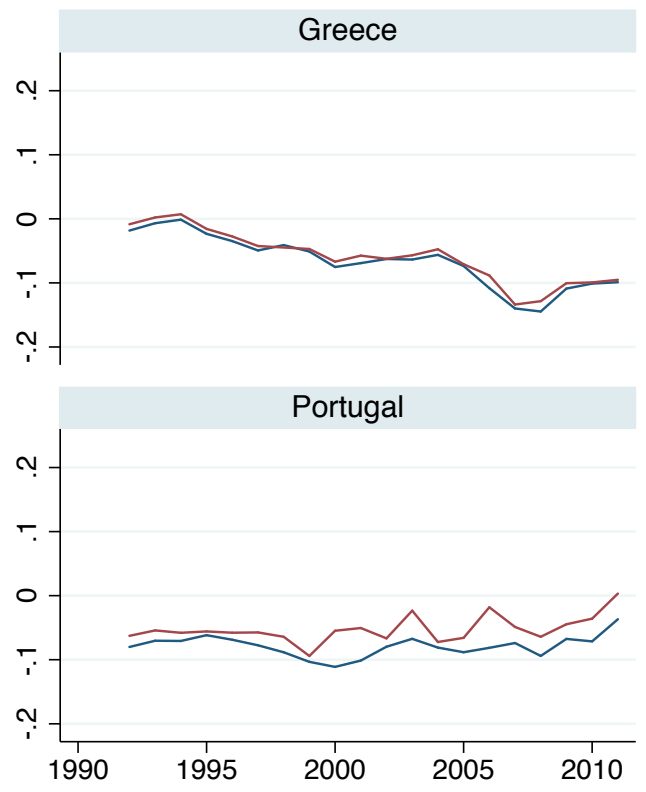

Current Account (\% GDP)
Ireland

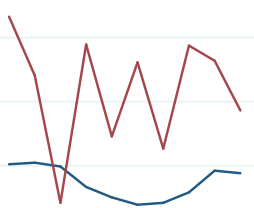

Spain

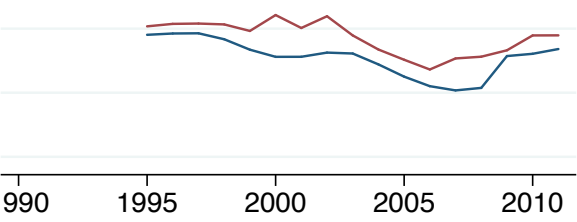

Current Account adjusted FDI (\% GDP)

Figure 10 - Current account adjusted by FDI - South of Europe and Ireland. 